\title{
Corporate Voluntary Disclosures in Emerging Markets: Empirical Evidence From the GCC Equity Markets
}

\author{
Antoine B. Awad \\ University of Doha for Science and Technology \\ Doha, Qatar \\ Lena A. Seissian (Corresponding author) \\ American University of Armenia \\ 40 Marshal Baghramyan Ave., Yerevan 0019, Republic of Armenia \\ Tel: 374-10-324-040Ｅ-mail: 1seissian@aua.am
}

Robert T. Gharios

American University of Science and Technology

Ashrafieh, Alfred Naccache Avenue, P.O.Box 16-6452, Beirut, Lebanon

Received: January 10, 2022

Accepted: February 7, 2022 Published: February 17, 2022

doi: 10.5296/ijafr.v12i1.19453

URL: https://doi.org/10.5296/ijafr.v12i1.19453

\begin{abstract}
In their path of searching for additional sources of information for better-informed decision-making process, market participants are presented with Voluntary disclosures. This paper aims at examining the determinants of voluntary disclosures in the GCC countries. A cross-sectional multiple regression analysis with a sample size of 74 listed firms from the GCC equity markets shows that leverage and economic sectors dominated mainly by "Real Estate" and "Services/Insurance", have statistically significant impact on voluntary disclosure. A remarkable finding of this paper indicates that the profitability variable measured in terms of return on equity (ROE) significantly explains the variation in the voluntary disclosure score in all sectors except for the "Services/Insurance" one.
\end{abstract}

Keywords: Voluntary disclosures, Gulf Cooperation Council, Transparency, Leverage, ROE, Economic sectors 


\section{Introduction}

"Voluntary Disclosures", a relatively new trend defined as "the information provided willingly to the public by the management's discretion" deepened its existence in corporate disclosure practices during the past twenty years. This practice was further stressed after the global financial crisis highlighted the lack of transparency and disclosure in corporate governance. In fact, the global community is growing increasingly concerned with transparency and disclosure in the corporate governance system (Eng \& Mak, 2003) as various scandals in developed countries have occurred due to lack of proper transparency and timely disclosure, such as the LIBOR scandal. These scandals have left tread marks in history because they exposed failures in corporate governance that shook capital markets in developed countries as well as developing ones. These scandals did not only have an effect on developed countries but on developing ones as well.

As a result, various emerging markets are unsure about the future of the corporate governance system as they do not possess the institutions that dissolve such negative effects. In light of this, reform programs have been launched by various emerging capital markets, led by the international capital provider, the International Finance Corporation (IFC), and the World Bank (Laksmana, 2008). Despite that, according to Baydoun et al. (2013), many developing countries are finding disclosure as one of the most significant challenges to the implementation of corporate governance.

Moving into the more technical side, Voluntary disclosure, in annual reports refers to the level of information reported beyond of what was required as content to be placed in the financial statements (Hossain \& Hammami, 2009). Basically, voluntary disclosures consist of a means to disclose further material based on the incentives of management (Healy \& Palepu, 2001). Governments, establishments, business organizations, and society at large have all become aware of the importance of companies presenting information extensively, whether it has to do with both their financial and non-financial performance.

The whole concept starts from the notion that investors have the right to be knowledgeable about the companies in which they are investing their money since they often take decisions regarding their investments based on the information disclosed in the company's reports. Consequently, providing sufficient information in company reports for investors to review and build upon is crucial and reduces the likelihood of making the wrong investment choices. Besides, the change in the environment and the increase in business complexity are giving rise to additional demands for information (Al-Janadi, \& Abdul Rahman, \& Haj Omar, 2013). Companies satisfy this demand by voluntarily supplying added information in their annual reports. Traditionally, the top mean was to print and mail these reports to stockholders. However, lately, a new trend Internet Financial Reporting (IFR) took center stage as the fastest and most cost-effective mean of communicating annual reports to interested users.

While IFR is booming in most western countries, there is little empirical evidence of this occurring in Gulf Cooperation Council (GCC) countries. Hence, understanding the factors of voluntary disclosure as well as its fusion with the internet is significant since managers may use the information to promote corporate transparency. 


\section{MlMacrothink}

International Journal of Accounting and Financial Reporting

ISSN 2162-3082

2022, Vol. 12, No. 1

Furthermore, according to Uyar \& Kilic (2012), mandatory disclosure primarily focuses on the presentation of financial statements and their complementary footnotes which are required by regulations and laws, whereas voluntary disclosure allows the management the freedom to choose which information to disclose. Recently, the scope of business reports has been expanding to cover non-financial activities of the firms along with financial outcomes. The delivery of a full public disclosure benefits investors and other stakeholders such that they become more conscious of companies' financial outcomes as well as non-financial aspects like social responsibility, environmental concern, employees, customers, and so on. By having a full public disclosure, firms will reduce the asymmetrical information problem between stakeholders and managers, reduce agency costs, and legitimize their activities. Moreover, Singhvi and Desai (1971) indicated that inadequate disclosures in annual reports are likely to cause fluctuations in the share prices since investment decisions are based on less objective measures in the absence of sufficient information. Furthermore, firms that have a low level of transparency might have difficulty in finding capital to finance their operations or at least would incur a higher cost of capital (Elliott \& Jacobson, 1994). This study scrutinizes the factors of voluntary disclosure in emerging market situations, GCC in specific.

As the purpose of this study is to examine the disclosure levels of GCC countries in an attempt to entice and motivate governing bodies and firms to improve the weak transparency levels by working on its determinants. With this paper the researchers will answer two main questions: First, about the existence of any difference in voluntary disclosure practices across the various sectors in the GCC countries and second, about the determinants of voluntary disclosures among a selection of variables, namely; profitability, leverage, role duality, type of auditing firm, Board independence, and number of board meetings.

The remainder of the paper proceeds as follows: Section 2 reviews the literature work. Section 3 describes the methodology adopted in details. The results of the empirical investigation are presented in Section 4. The analysis of the results is explained in Section 5. Finally, a summary and direction for future research are presented in Section 6.

\section{Literature Review}

Investment requires trust, which in turn depends on transparency. Nowadays, it is easier for companies to divulge information via the internet. Communication plays a large part in a company's success, and an improvement in the means and methods of communication, such as reductions in cost or further ease of dissemination, will encourage companies to disclose information more thoroughly and more frequently.

\subsection{Financial Reporting and Transparency}

Disclosures are a key determinant of transparency, and the two constitute the fundamentals of corporate governance. Better disclosures promote transparency and hence reduce information asymmetry between the various stakeholders of the firm. Firms with higher transparency and voluntary disclosures are seen as more valuable and treasured as opposed to their counterparts who do not exhibit the same level of these qualities (Patel, S. \& Dallas, G., 2002). Financial reports, whether annual or quarterly, help monitor the firm's activities and 
scrutinize management decisions. These reports are a primary source of information for many stakeholders, being investors, creditors, employees, the government, and even regulatory bodies. Investors rely heavily on financial reports for the sake of obtaining both financial and non-financial information on the company and to carry out decisions based on said information (Neu et al., 1998).

Many theories have emerged over the years as to why firms would voluntarily disclose information and why transparency is a crucial aspect of any firm's activities and reporting on such activities. There are many incentives and benefits to willingly disclose information, yet some firms still abstain from doing so. This can perhaps be explained by high costs of gathering, processing, and publishing information. Moreover, a continuous concern of firms is the proprietary costs that can stem from the dissemination of too much information.

\subsection{Voluntary Disclosure Practices}

Disclosures are essential to users for the sake of informed decision-making regarding investment and valuation (Charumathi \& Ramesh, 2015). There are three main determinants to voluntary disclosures: firm size, extent of institutional ownership, and profitability. Cerf (1961) also adds that the number of shareholders as a key determinant. Moreover, institutional ownership insinuates a larger number of stakeholders who will push for better disclosure, giving companies a greater sense of responsibility when divulging information (Charumathi \& Ramesh, 2015). Additionally, the more profitable a company, the greater it was found to disclose information due to stock market pressure and the need to acquire external capital (Basuony \& Mohamed, 2014).

Furthermore, the agency cost theory states that information asymmetry among market participants will lead to higher agency costs. The reduction of said costs entails firms to better disclose relevant information. Agency costs are believed to be positively correlated to firm size (Hossain et al, 1995). Disclosures can reduce one of the significant agency costs: monitoring costs. Accordingly, it is expected that large firms would have a higher level of disclosure than small firms. Smaller companies were found to hide important information, such as that pertaining to poor financial performance, in order to survive industrial competition. Voluntary disclosure may further reduce agency costs by allowing creditors to further assess companies' ability to meet their debt obligations (Basuony \& Mohamed, 2014). Highly leveraged companies are thus inclined to disclose information that would influence creditors' decision-making and promote confidence in the firm's ability to meet debt obligations.

Conversely, the signaling theory can be used to explain the relationship between some characteristics such as profitability and the level of voluntary disclosure. Managers of a profitable firm may choose to disclose information that signals the firm's profitability in order to help management's continuation and compensation (Singhvi and Desai, 1971; Malone et al., 1993). An occurrence of a negative correlation has been found between the quality of disclosures and profitability. Companies whose performance has been poor are more prone to disclose information related to their current performance and not to their past, focusing solely on their improvement (Dyczkowska, 2014). This hinders investors' ability to 
make informed decisions based on companies' past performance. This, however, cannot be conclusively generalized.

Industry type is also an important factor in determining voluntary disclosures. Companies will generally adopt similar disclosure practices as their industry peers, and those who do not will be regarded as potentially hiding information, thus scaring away potential investors.

Barako et al. (2006) found that the presence of an audit committee was the chief factor in increasing the level of voluntary disclosure, while profitability had little to no effect. Their study also found little relation between external auditors and voluntary disclosures. The proportion of foreign ownership was found to have a significant positive correlation with the extent of voluntary disclosure due to foreign reporting requirements. Similarly, Uyar et al. (2013) also found no relation between profitability and voluntary disclosures, while leverage and ownership diffusion were found to have a negative influence. High diffusion entails a diversified shareholder base, which is thought to have less direct interest in the firm's disclosures. Management of companies with highly diffused ownership also tend to disclose less information, preventing any harm to the firm's competitive position in the market (Uyar et al., 2013).

Firms audited by the Big Four auditors have better resources and opportunities to disclose financial information (Kolsi, 2012). Auditors encourage their clients to disclose more information in order to avoid incurring litigation costs due to absence of information.

\subsection{Measurement by Dichotomous Approach}

Previous studies (Buzby, 1974; Wallace, 1987; Cooke, 1989, 1991, 1992; Karim, 1995; Hossain et al, 1994; Ahmed and Nicholls, 1994; and Hossain, 2000; Barako et al., 2006; Hossain and Hammami, 2009; Hussainey \& Walker, 2009; Bruslerie et al., 2010) that focused on the capture of disclosure level have utilized a dichotomous approach which can be divided into two categories: weighted and unweighted. The weighted approach is derived by assigning a weight to each item of information in the disclosure index based on a range of factors, such as its pertinence in the study, its importance for the users of the company's information. As for the unweighted method, items either receive a weight if they are disclosed or null if they are not. The weighted approach can be seen in many previous studies, of which Copeland et al., (1968), Singhvi \& Desai (1971), Barett (1977), Courtis (1978), Eng and Mak (2003), Naser and Nuseibeh (2003), Arcay and Vasquez (2005), and Francis et al. (2008). These researchers believe that certain types of information are of greater significance than others; thus, they use their professional judgement to assign weights accordingly.

Despite the popularity of the weighted model, this paper employs the unweighted dichotomous approach, which basically allocates equal weights to all the items of information incorporated in the disclosure index. If an item is the subject of disclosure, the firm receives a one, otherwise it receives a zero. Even though the "unweighted approach provides all items of information equally, it evades the subjective verdict of assigning weights to disclosure items" (Al-Shattarat W.K., Haddad A.E., \& Al-Hares O.M., 2010). The unweighted approach was used by many earlier researchers such as Chow et al. (1987), Cooke (1989), Ahmed \& 
Nicholls (1994), Wallace et al. (1994), Wallace \& Naser (1995), Akhtaruddin (2005), Haniffa and Cooke (2002), Ghazali and Weetman (2006), Bruslerie et al. (2010), Al-Shattarat, Haddad, \& Al-Hares (2010) and Omar \& Simon (2011). A detailed Table, Appendix A, summarizes the previous research work with the empirical field, methodology and the averages of Voluntary Disclosure.

\subsection{The Determinants of Voluntary Disclosures}

\section{- Profitability and Performance}

Companies with a good track record have been found to willingly disclose information that shows their sound performance, while companies who have been experiencing consistent losses or only just have begun to generate profits will omit certain information and only release that which shows improvement (Singhvi and Desai, 1971; Malone et al., 1993; Wallace et al., 1994; Haniffa and Cooke, 2002; Basuony and Mohamed, 2014). Dyczkowska (2014) confirms this theory by stating that companies whose historical performance was weak and have only recently improved will generally hide information pertaining to their lower performance and put recent years in the spotlight, which would lead to misinformation or poor decisions on behalf of investors. Furthermore, a number of studies have found that firms who generate a higher profitability in terms of indicators such as ROA or ROE have more incentive to disclosure additional information voluntarily, as per the "signaling theory" (Prencipe, 2004; Wang, Sewon, \& Claiborne, 2008; Kolsi, 2012).

An interesting perspective regarding agency theory states that management of highly profitable firms will be more likely to disclose additional information in order to secure personal advantages, such as high compensation or maintaining their position (Singhvi and Desai, 1971). This paper definitely tackles this construct by testing the below hypothesis:

$\mathrm{H}_{1}$ (null): The firm's profitability is not positively associated with its level of voluntary disclosures.

\section{- Leverage}

Leverage is the use of borrowed money, often referred to as borrowed capital, to boost the potential return of an investment. With reference to the agency theory, Leftwich (1981) pointed out that firm with excess leverage level tend to have higher agency costs of loan capital. Hence, voluntary disclosures help these firms decrease their agency costs simply by sharing more credible information to the suppliers of capital (Jensen and Meckling, 1976).

A leveraged firm would be facing debt covenants put in place by lenders in order to protect their interests, the result of which would be the disclosure of additional information (Jensen and Meckling, 1976). The reduction of information asymmetry between a company and its lenders can in turn reduce the cost of debt and increase its chance of acquiring funds from financial institutions. El Ghazzar et al. (2008) found that companies facing higher levels of leverage will willingly disclose additional information in order to attract debt holders' trust. Using a variant of Standard and Poor's Transparency \& Disclosure 98 desirable attributes, Aksu and Kosedag (2006) find no relation between leverage and the level of voluntary 
disclosure exhibited by firms. Other studies (Chow et al., 1987; Brennan and Hourigan, 2000; Debreceny et al., 2002; Larran and Giner, 2002; Oyelere et al., 2003; Bollen et al., 2006; Ezat and El-Masry, 2008; Al-Shammari and Al-Sultan, 2010; Basuony and Mohamed, 2014) failed to find a significant relationship between leverage and the firm's disclosure level. Nevertheless, some other empirical studies (Robbins \& Austin, 1986; Mitchel et al., 1995; Hossain et al., 1995; Meek et al., 1995, Xiao et al., 2004; Karim et al., 2005; Bruslerie et al., 2010; Omar et al., 2011) observed a substantial relationship between the firm's leverage level and its disclosure level. From the same token, this paper addresses the impact of leverage and the amount of voluntary disclosures by testing the below hypothesis:

$\mathrm{H}_{2}$ (null): The firm's leverage is not positively associated with its level of voluntary disclosures.

\section{- External Audit}

Firms audited by the Big Four have a better level of disclosure (Kolsi, 2012). External auditing puts companies under added monitoring (Raffournier, 1995). Given that the Big Four have an international standing and exposure, they are more likely to advise their clients to disclose more information (Chow \& Boren, 1987). DeAngelo (1981) explains that large audit firms invest more in order to maintain their reputation as providers of sound auditing services and that they have a larger stake in not seeing their reputation damaged, seen as their value as auditors depends on financial information users' perception of their audit report. Healy and Palepu (2001) identified that companies that hire international audit firms are perceived by the public as being highly transparent.

A study of 170 Kuwaiti companies by Al-Shammari \& Al-Sultan (2010), proved that the type of auditing firm is not a significant factor that impacts the disclosure level of firms. Moreover, some other studies (Wallace et al., 1994; Hossain et al., 1995; Abd El Salam, 1999; Aly et al., 2010; Basuony and Mohamed, 2014) did not also detect any significant relation between the type of auditing firm and disclosure. Conversely, Ahmed and Nicholls (1994), Raffournier (1995), Xiao et al. (2004), and Boubaker et al., (2012) succeeded to determine a major significant relation between these two variables. The study herein investigates the type of external audit used and its effect on voluntary disclosure, by testing the following hypothesis:

$\mathrm{H}_{3}$ (null): The type of auditing firm is not positively associated with a firm's level of voluntary disclosures.

\section{- Industry Type}

It is likely that the level of disclosure would differ across the various sectors of the economy. This can be explained by a number of reasons. For instance, Japan has experienced a phenomenal economic growth and efficiency in manufacturing (Lincoln and Kalleberg, 1990) that have attracted international exposure to it. Furthermore, historically during the total war years, accounting in certain businesses was heavily regulated (Choi and Hiramatsu, 1987). While most of these regulations were nullified following the end of World War II, it is possible that they've had a long-lasting effect on the governance mechanisms of the manufacturing sector (Cooke, 1992). Cooke (1989) also finds historical reasons to be a factor 
in explaining the development in financial reporting of Swedish companies that fall into the manufacturing, trading, services, or conglomerate type.

There are various studies that tested the impact of the industry on the internet financial disclosure. The literature revealed that many researchers (Ashbaugh et al., 1999; Craven and Marston, 1999; Brennan and Hourigan, 2000; Bonson and Escobar, 2002; Garci'a-Borbolla et al., 2005; Ismail, 2002; Oyelere et al., 2003; Ezat and El-Masry, 2008) proved that the type of industry is an influential factor on the internet financial disclosures while others (Debreceny and Rahman, 2005; Larran and Giner, 2002; Trabelsi and Labelle, 2006; Basuony and Mohamed, 2014) failed to detect a significant relation between the two variables. In this paper, the selected companies belong to various economic sectors: consumer staples, financial services and banks, industrial, real estate, services and insurance, and technology and telecommunication. Consequently, it is evident to identify whether there are any significant differences in their voluntary disclosure levels by testing the below hypothesis:

$\mathrm{H}_{4}$ (null): There is no significant difference in the voluntary disclosure mean score across various sectors in the GCC.

\section{- Non-Executive Directors}

Companies employ executive (insider) and non-executive (outsider) directors on their boards. Executive directors are generally full-time employees of the firm while non-executive directors are not in any way affiliated with the company (Haniffa and Cooke, 2002; Weir and Laing, 2001). Studies point in the direction that supports a larger number of non-executive directors on the board being a catalyst that increase the level of voluntary disclosures. Outside directors are also largely responsible for higher levels of disclosures since they increase the independence of the board in exercising its supervision over management and are not prone to align with management (Chen and Jaggi, 2000; Eng and Mak, 2003). The board must continuously monitor management in order to avoid opportunistic behavior (Berle and Means, 1932; Jensen and Meckling, 1976; Mangel and Singh, 1993). Outside directors, whose incentives are supported by their equity position and their responsibility as directors, will have a better control vantage point. Many studies have shown that outside directors might be decision-making experts and are not as easily intimidated by the CEO, and generally act as a positive influence over the BOD's deliberations.

Lastly, a study of Al-Shammari and Al-Sultan (2010) encompassing 170 Kuwaiti firms revealed that the non-executive directors on the board is not a significant factor that impacts the firms' disclosure levels. At this point, the below hypothesis is derived to measure the effect of board independence in the GCC on the level of voluntary disclosure.

$\mathrm{H}_{5}$ (null): The board's independence is not positively associated with a firm's level of voluntary disclosures.

\section{Literature Critical Assessment}

A rigorous assessment of the literature compelled the researchers to embark into this exact research work. To start up, the previous work presented evidence from individual countries 


\section{Mll Macrothink}

International Journal of Accounting and Financial Reporting

ISSN 2162-3082

hence providing a push for a similar work to be done on a specific geographical area such as the Gulf Countries. Moreover, the previous existing literature from the Gulf region discusses and evaluates mainly a specific sector, financial services, which is already highly regulated. There is no updated, collective research work studying the factors that determine disclosure. Hence, this work comes to fill out this gap. Finally, there is no empirical study revealing the level of transparency/ disclosure practices of Gulf countries, keeping in mind that these countries regard closely traditions and secrecy. This work will also address that reality.

\section{Research Methodology}

This paper adopted a multimethod quantitative study that involves more than one data collection technique used with associated analysis procedures. This confirms Bryman's (2006) finding that state that multiple methods are increasingly utilized in business and management research. This research involved two data collection techniques. The first was via the 2015 annual reports of all the firms while the second relied on a Bloomberg terminal to extract various financial indicators. As for the analytical procedures, this work used ANOVA and multiple ordinary least square regressions to answer the research questions.

\subsection{Research Sample}

The research sample of this research is selected using a probability sampling technique which is stratified random sampling. As a result, the researcher has divided the entire population, which is all the stock markets of the GCC, into two strata which are the country and the sector. These strata encompass six GCC countries and six sectors as shown in the following table.

Table 1. Sample Strata

\begin{tabular}{ll}
\hline Stratum by Country & Stratum by Sector \\
\hline Saudi Arabia & Consumer Staples \\
United Arab Emirates & Financial Services \& Banks \\
Kuwait & Industrial \\
Bahrain & Real Estate \\
Oman & Services \& Insurance \\
Qatar & Technology \& Telecommunication \\
\hline
\end{tabular}

The total number of firms listed in the GCC financial markets was 811 as of December 31, 2015. The main criteria for sampling the firms were: (i) annual reports must be available for the 2015 in English and (ii) the firm must have been listed for the entire year 2015 which is the period of the study. The chosen sample size was 80 companies, however; six firms have been excluded as they did not meet the abovementioned criteria. Hence, the final sample size of this research represents 74 . 


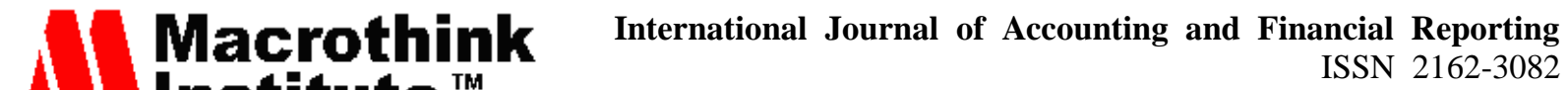

Table 2. Selected Sample Summary

\begin{tabular}{|c|c|c|c|c|c|c|c|c|}
\hline $\begin{array}{c}\text { Country / } \\
\text { Sector }\end{array}$ & $\begin{array}{c}\text { Consumer } \\
\text { Staples }\end{array}$ & $\begin{array}{c}\text { Financial } \\
\text { Services } \\
\text { \& Banks }\end{array}$ & Industrial & $\begin{array}{c}\text { Real } \\
\text { Estate }\end{array}$ & $\begin{array}{l}\text { Services \& } \\
\text { Insurance }\end{array}$ & $\begin{array}{c}\text { Technology \& } \\
\text { Telecommunication }\end{array}$ & Total & $\begin{array}{c}\% \text { of } \\
\text { Attribution } \\
\text { By Country }\end{array}$ \\
\hline $\begin{array}{l}\text { Saudi } \\
\text { Arabia }\end{array}$ & 2 & 3 & 4 & 2 & 6 & 1 & 18 & $24 \%$ \\
\hline UAE & 1 & 4 & 1 & 2 & 3 & - & 11 & $16 \%$ \\
\hline Kuwait & 1 & 7 & 3 & 4 & 6 & - & 21 & $28 \%$ \\
\hline Bahrain & - & 4 & 1 & - & 2 & 2 & 9 & $12 \%$ \\
\hline Oman & 1 & 7 & 2 & - & - & - & 10 & $13 \%$ \\
\hline Qatar & - & 2 & 1 & 1 & 1 & - & 5 & $7 \%$ \\
\hline Total & 5 & 27 & 12 & 9 & 18 & 3 & 74 & \\
\hline \multicolumn{9}{|l|}{$\%$} \\
\hline $\begin{array}{l}\text { Attribution } \\
\text { by Sector }\end{array}$ & $7 \%$ & $36 \%$ & $16 \%$ & $12 \%$ & $24 \%$ & $5 \%$ & & \\
\hline
\end{tabular}

The researchers consider that this sample is representative of the population since the final sample size represents around 9.12 percent of the whole population.

\subsection{Development of Voluntary Disclosure Measurement}

The information gathering process was done through content analysis of the GCC annual reports of year 2015 which were selected and downloaded from the company web sites. The annual reports were thoroughly read in order to score, analyze, and evaluate their levels of voluntary disclosure in relation to transparency.

This work has adopted the voluntary disclosure index developed by Hossain and Hammami (2009) to evaluate the voluntary disclosure level of every firm selected in the sample composed of 44 items grouped into eight categories: Background about the Firm/General Corporate Information, Corporate Strategy, Corporate Governance, Financial Performance, General Risk Management, Accounting Policy Review, Corporate Social Disclosure, and Other.

\subsection{Measurement by Dichotomous Approach}

The scoring process in this research utilized the unweighted (dichotomous) approach. If the item is disclosed on, the firm receives a one, and if not, it receives a zero. Even though the unweighted approach provides all items of information equally, it evades the subjective verdict of assigning weights to disclosure items (Al-Shattarat et al., 2010).

\subsection{Voluntary Disclosure Scoring Mechanism.}

A scoring sheet was developed for each of the firms selected in order to assess the extent of voluntary disclosure as a proxy for its transparency level. For every disclosed item, it receives a score of 1 and 0 otherwise. According to Popova et al. (2013), the unweighted index is the ratio of the firm's disclosure score divided by the total disclosure score derived as expressed by the following equation: 


$$
\operatorname{VDS}=\sum_{\mathbf{i}=\mathbf{1}}^{\mathbf{n}} \quad \underline{d}_{\underline{\mathrm{i}}}
$$

Where:
VDS Aggregate Voluntary Disclosure Score
$\mathbf{d}_{\mathbf{i}} \quad 1$ if the $\mathrm{i}^{\text {th }}$ item is disclosed or 0 if it is not disclosed
n the maximum score each firm can obtain.

\subsection{Model Specification and Econometric Concerns}

The researchers formulated the first model relying on OLS regression model to study the factors that determine the dependent variable. The following model represents the general form of the ordinary least square (OLS) regression model which reveals the voluntary disclosure score as a dependent variable.

$$
\begin{aligned}
\operatorname{VDS}_{\mathrm{t}, \mathrm{i}}= & \beta_{0}+\beta_{1} \mathrm{ROE}_{\mathrm{t}, \mathrm{i}}+\beta_{2} \mathrm{DR}_{\mathrm{t}, \mathrm{i}}+\beta_{3} \mathrm{BFAF}_{\mathrm{t}, \mathrm{i}}+\beta_{4} \mathrm{Bind}_{\mathrm{t}, \mathrm{i}}+\beta_{5} \mathrm{IND}_{\mathrm{i}, \mathrm{CS}}+\beta_{6} \mathrm{IND}_{\mathrm{i}, \mathrm{RE}}+\beta_{7} \mathrm{IND}_{\mathrm{i},} \\
& \mathrm{S} / \mathrm{I}+\beta_{8} \mathrm{IND}_{\mathrm{i}, \mathrm{Ind}}+\beta_{9} \mathrm{IND}_{\mathrm{i}, \mathrm{FSB}}+\beta_{10} \mathrm{IND}_{\mathrm{i}, \mathrm{TT}}+\varepsilon
\end{aligned}
$$

Where:

t: The year of study

i: The $i^{\text {th }}$ firm selected

$\varepsilon:$ The error term

As for the explanatory variables, the choices were set on:

Return on equity (ROE): as a proxy for profitability.

Debt-to-assets ratio (DR): as a proxy for leverage.

Big four auditing firms (BFAF). Many of the GCC firms selected in this study are audited by the "Big Four" which are the four leading professional service networks in the world primarily consisting of Ernst \& Young, Deloitte \& Touche, KPMG, or Price Waterhouse Coopers.

Board independence (BInd). A board with a higher percentage of non-insiders as opposed to another with a lower percentage is presumed to be more effective at monitoring management (Kim et al., 2010).

Industry. This variable represents the type of industry of each company in the sample size. Each firm in the sample belongs to one of the following industries: Consumer Staples (CS), Real Estate (RE), Services/Insurance (S/I), Industrial (Ind), Financial Services and Banks (FSB), and Technology and Telecommunication (TT). 


\section{Macrothink \\ International Journal of Accounting and Financial Reporting \\ ISSN 2162-3082 \\ 2022, Vol. 12, No. 1}

\section{Results, Findings, and Discussions}

\subsection{Descriptive Analysis}

The researchers were able to extract some interesting and insightful information from the collected data. They start with the breakdown of VDS scores for all selected firms. This is detailed in Table 3. The table shows the breakdown of the voluntary disclosure scores for all the selected firms. The results reveal that there is an excessive variation in the scores. It shows that 35 firms (47\% of the sample) out of the 74 scored below 50 percent on the voluntary disclosure index. A study of Hossain and Hammami (2009) which revealed that the 86 percent of all the firms listed (25 firms) in the Doha Securities Market (DSM) showed that 23 out of 25 companies got lower than 50 percent. This indicates that the transparency level in the GCC countries has improved tremendously between the date of the previous study (2007) and the current study (2015).

Table 3. Total Voluntary Disclosure Score Breakdown

\begin{tabular}{ccc}
\hline Score & Number of Firms & $\begin{array}{c}\text { Cumulative } \\
\text { Numbers }\end{array}$ \\
\hline $0-10$ & $0(0 \%)$ & $0(0 \%)$ \\
$11-20$ & $0(0 \%)$ & $0(0 \%)$ \\
$21-30$ & $10(13 \%)$ & $10(13 \%)$ \\
$31-40$ & $12(16 \%)$ & $22(29 \%)$ \\
$41-50$ & $13(18 \%)$ & $35(47 \%)$ \\
$51-60$ & $14(19 \%)$ & $49(66 \%)$ \\
$61-70$ & $14(19 \%)$ & $63(85 \%)$ \\
$71-80$ & $10(14 \%)$ & $73(99 \%)$ \\
$81-90$ & $1(1 \%)$ & $74(100 \%)$ \\
$90-100$ & $0(0 \%)$ & $74(100 \%)$ \\
Total & $\mathbf{7 4}$ & \\
\hline
\end{tabular}

For further analysis, the next table (Table 4) shows a detailed breakdown of the score as per each category in the index. The index encompassed eight categories as follows: Background about the Firm (A), "Corporate Strategy" (B), "Corporate Governance" (C), "Financial Performance" (D), "General Risk Management" (E), "Accounting Policy Review" (F), "Corporate Social Disclosure" $(\mathrm{G})$, and "Others" $(\mathrm{H})$. The results disclose that the majority of the firms are scoring above 50 percent on the Background (83 percent of the firms), Corporate Strategy (77 percent of the firms), General Risk Management (78 percent of the firms), and Accounting Policy Review (57 percent of the firms. This sounds to be reasonable as all the firms are imposed by their local laws and international financial reporting standards to fully disseminate information about their risk management procedures in addition to their accounting policies.

Conversely, the results proved that the firms in the GCC should improve their disclosure level when it comes to Corporate Governance, Financial Performance, Corporate Social Disclosure, and Other relevant data for financial users. The majority of the firms scored 
below 50 percent of the abovementioned categories. Most of the GCC firms are still lagging behind in terms of disclosing information related to their corporate governance procedures, financial performance indicators, and/or corporate social responsibility activities (CSR) activities. These results confirm the findings of Hossain and Hammami (2009) in Qatar when they found out that most of the Qatari firms lack the disclosure of corporate governance procedures and CSR activities. Moreover, it also confirms the findings of Al-Janadi et al. (2013) about Emirati and Saudi firms where they obtained relatively lower scores on social and environmental disclosure as well as corporate governance disclosure.

Table 4. Voluntary Disclosure Categories Breakdown

\begin{tabular}{|c|c|c|c|c|c|c|c|c|}
\hline \multicolumn{9}{|c|}{ Number of Firms } \\
\hline Score & BG (A) & C.S. (B) & C.G. (C) & F.P. (D) & $\begin{array}{c}\text { G.R.M. } \\
\text { (E) }\end{array}$ & $\begin{array}{c}\text { A.P.R. } \\
\text { (F) }\end{array}$ & C.S.D. (G) & $\begin{array}{l}\text { O. } \\
\text { (H) }\end{array}$ \\
\hline $0-10$ & $0(\mathbf{0 \%})$ & $17(\mathbf{2 3} \%)$ & $15(20 \%)$ & $3(4 \%)$ & $1(\mathbf{1 \%})$ & $2(3 \%)$ & $30(41 \%)$ & $1(\mathbf{1 \%})$ \\
\hline $11-20$ & $2(3 \%)$ & $0(\mathbf{0 \%})$ & $10(\mathbf{1 4 \%})$ & $14(\mathbf{1 9 \%})$ & $1(1 \%)$ & $0(\mathbf{0 \%})$ & $0(\mathbf{0 \%})$ & $14(\mathbf{1 9 \%})$ \\
\hline $21-30$ & $0(\mathbf{0 \%})$ & $0(\mathbf{0 \%})$ & $3(4 \%)$ & $0(\mathbf{0 \%})$ & $7(9 \%)$ & $0(\mathbf{0 \%})$ & $0(\mathbf{0 \%})$ & $12(\mathbf{1 6 \%})$ \\
\hline $31-40$ & $9(12 \%)$ & $0(\mathbf{0 \%})$ & $3(4 \%)$ & $21(\mathbf{2 8 \%})$ & $7(9 \%)$ & $0(\mathbf{0 \%})$ & $13(\mathbf{1 8 \%})$ & $13(\mathbf{1 8 \%})$ \\
\hline $41-50$ & $1(\mathbf{1 \%})$ & $0(\mathbf{0 \%})$ & $9(12 \%)$ & $6(8 \%)$ & $0(\mathbf{0 \%})$ & $15(20 \%)$ & $0(\mathbf{0 \%})$ & $25(34 \%)$ \\
\hline $51-60$ & $18(\mathbf{2 4 \%})$ & $16(22 \%)$ & $11(\mathbf{1 5 \%})$ & $15(20 \%)$ & $11(\mathbf{1 5 \%})$ & $0(\mathbf{0 \%})$ & $0(\mathbf{0 \%})$ & $0(\mathbf{0 \%})$ \\
\hline $61-70$ & $21(\mathbf{2 8 \%})$ & $0(\mathbf{0 \%})$ & $6(8 \%)$ & $10(\mathbf{1 4 \%})$ & $17(\mathbf{2 3} \%)$ & $0(\mathbf{0 \%})$ & $14(\mathbf{1 9 \%})$ & $8(\mathbf{1 1 \%})$ \\
\hline $71-80$ & $0(\mathbf{0 \%})$ & $0(\mathbf{0 \%})$ & $9(12 \%)$ & $0(\mathbf{0 \%})$ & $18(\mathbf{2 4 \%})$ & $0(\mathbf{0 \%})$ & $0(\mathbf{0 \%})$ & $1(\mathbf{1 \% )}$ \\
\hline $81-90$ & $14(\mathbf{1 9 \%})$ & $0(\mathbf{0 \%})$ & $3(4 \%)$ & $5(7 \%)$ & $8(\mathbf{1 1 \%})$ & $0(\mathbf{0 \%})$ & $0(\mathbf{0 \%})$ & $0(\mathbf{0 \%})$ \\
\hline $91-100$ & $9(\mathbf{1 2 \%})$ & $41(\mathbf{5 5 \%})$ & $5(7 \%)$ & $0(0 \%)$ & $4(5 \%)$ & $57(77 \%)$ & $17(\mathbf{2 3 \%})$ & $0(\mathbf{0 \%})$ \\
\hline Total & 74 & 74 & 74 & 74 & 74 & 74 & 74 & 74 \\
\hline
\end{tabular}

On the opposite spectrum, the Accounting Policy Review category achieved the highest average which is 89 percent. This is due to the strict financial reporting standards imposed by local and international authorities. Furthermore, the above scores demonstrate that the GCC firms should voluntarily disseminate supplementary information related to corporate governance procedures, financial performance, and corporate social disclosure.

Besides, the following table (Table 5) illustrates some statistics related to the total voluntary disclosure scores. This table indicates that the average voluntary disclosure score is 51 percent with a minimum score of 20 percent and a maximum of 84 percent. These results contradict the results of previous published studies such as Hossain and Hammami (2009) in Qatar (37\%), Adawi and Rwegasira (2011) in UAE (36\%), Leventis and Weetman (2004) in Greece (37\%), Al-Shammari (2008) in Kuwait (46\%), Al-Shammari and Al-Sultan (2010) in Kuwait (19\%), Uyar et al. (2013) in Turkey (44\%), and Ghazali and Weetman (2006) in Malaysia (31\%) that obtained lower voluntary disclosure scores. On the other hand, other studies such as Al Mamum and Kamardin (2014) in Bangladesh indicates that there was an improvement in the voluntary disclosure scores of the firms between the year $2005(69 \%)$ and $2008(76 \%)$. 


\section{Macrothink \\ International Journal of Accounting and Financial Reporting

Table 5. Voluntary Disclosure Scores Descriptive Statistics

\begin{tabular}{ll}
\hline \multicolumn{2}{l}{ Descriptive Statistics } \\
\multicolumn{2}{l}{ Total Voluntary Disclosure Score } \\
$\mathrm{N}$ & Valid \\
Mean & 74 \\
Std. Deviation & 50.746 \\
Skewness & 17.375 \\
Std. Error of Skewness & -.085 \\
Kurtosis & .279 \\
Std. Error of Kurtosis & -1.064 \\
Minimum & .552 \\
Maximum & 20.000 \\
\hline
\end{tabular}

In an attempt to determine the transparency level of each sector, presented in Table 6, the scores revealed that the "Consumer Staples" and the "Financial Services and Banks" sectors surpassed the remaining sectors. It is rational to determine that the "Financial Services and Banks" sector discloses more than the remaining due to the strict regulation environment imposed by central banks and international financial regulatory bodies. These results confirm the findings of Al-Janadi et al. (2012) when they found out that the financial sector has the highest disclosure level in Saudi Arabia and the UAE.

Furthermore, the results of the "Consumer Staples" sector might be biased upward and this shall lead to questionable findings due to (1) the small number of consumer staple firms selected in the sample and (2) the little evidence found in the literature that points out that the consumer staple firms are more transparent than financial institutions.

Nevertheless, the Real Estate and Services/Insurance sectors proved to be the least transparent as opposed to other sectors.

Table 6. Average Disclosure Score per Sector

\begin{tabular}{ll}
\hline Sector & Average Disclosure Score \\
\hline Consumer Staples & $62 \%$ \\
Financial Services \& Banks & $60 \%$ \\
Industrial & $54 \%$ \\
Technology \& Telecommunication & $48 \%$ \\
Real Estate & $43 \%$ \\
Services/Insurance & $40 \%$ \\
\hline
\end{tabular}

The following table (Table 7) presents the average voluntary disclosure score per country. The scoring results reveal that Oman is the leader in terms of voluntary disclosures among other GCC firms followed by Qatar and Bahrain. Kuwait, UAE, and KSA ranked as fourth, fifth, and sixth, respectively. There is little evidence in the literature related to the voluntary 


\section{Mll Macrothink}

International Journal of Accounting and Financial Reporting

ISSN 2162-3082

2022, Vol. 12, No. 1

disclosure level of each of the GCC countries. Nonetheless, Baydoun et al. (2013) have published an article related to the corporate governance in five Arabian Gulf countries and pointed out that Oman ranked the first in terms of corporate governance followed by Kuwait, UAE, Bahrain, and Qatar. Plus, Al-Janadi et al. (2012) have showed that the overall voluntary disclosure score of UAE companies is higher the one of Saudi companies. This result confirms the below findings where the Emirati firms proved to be more transparent than Saudi firms.

Table 7. Average Voluntary Disclosure Score per Country

\begin{tabular}{ll}
\hline Country & Average Disclosure Score \\
\hline Oman & $63 \%$ \\
Qatar & $62 \%$ \\
Bahrain & $57 \%$ \\
Kuwait & $48 \%$ \\
UAE & $49 \%$ \\
KSA & $45 \%$ \\
\hline
\end{tabular}

Moving to the empirical results, the first section discusses the question regarding any significant differences in VDS across the various sectors in the GCC countries. The decision was to carry out ANOVA Test (Analysis of Variance).

The following table (Table 8) shows the result of the ANOVA test for the first research question.

Table 8. ANOVA Output

\begin{tabular}{llllll}
\hline & Sum of Squares & df & Mean Square & F & Sig. \\
\hline Between Groups & 5797.473 & 5 & 1159.495 & 4.855 & .001 \\
Within Groups & 16241.048 & 68 & 238.839 & & \\
Total & 22038.521 & 73 & & & \\
\hline
\end{tabular}

With an $\mathrm{F}_{\text {STAT }}$ of 4.855 ( $p$ value $<0.01$ ), it is proven that the voluntary disclosure score of at least one of the groups (sectors) is not equal to that of the others. Hence, the above results prove empirically that the type of sector is affecting the voluntary disclosure score. There is a mean difference in the voluntary disclosure scores across certain sectors. These findings lead to reject the null hypothesis at the 1 percent alpha. Consequently, a post-hoc comparison test was used to determine which group's mean differs from that of the others. The one-way ANOVA $F$ test is relatively robust with respect to the assumption of equal group variances, large differences in the group can utterly impact the level of significance and the power of the $F$ test. 


\section{Macrothink}

International Journal of Accounting and Financial Reporting ISSN 2162-3082 2022, Vol. 12, No. 1

For this purpose, there should be a prior homogeneity of variance test to make sure that the variances of all the selected groups are equal. The choice was set on Levene Test.

Table 9. Test of Homogeneity of Variances for VDS

\begin{tabular}{llll}
\hline Levene Statistic & df1 & df2 & Sig. \\
\hline 1.375 & 5 & 68 & .245 \\
\hline
\end{tabular}

The above table (Table 9) shows that the Levene sTAT is 1.375 ( $p$ value > 0.05). This shall lead not to reject the null hypothesis that assumes that the variances across all sectors are equal. Hence, the above results prove empirically that the score variances across the six different sectors in the GCC are equal. The Tukey-Kramer test was applied due to the unequal sample size in each of the six selected groups. 
Table 10. Tukey-Kramer Multiple Comparisons

Dependent Variable: Total Voluntary Disclosure Score

Tukey HSD

\begin{tabular}{|c|c|c|c|c|c|c|}
\hline \multirow[t]{3}{*}{ (I) Industry } & \multirow[t]{3}{*}{ (J) Industry } & \multirow{3}{*}{$\begin{array}{l}\text { Mean } \\
\text { Difference } \\
(\mathrm{I}-\mathrm{J})\end{array}$} & \multirow[t]{3}{*}{$\begin{array}{l}\text { Std. } \\
\text { Error }\end{array}$} & \multirow[t]{3}{*}{ Sig. } & \multirow{3}{*}{$\begin{array}{l}95 \% \\
\text { Interval } \\
\text { Lower } \\
\text { Bound }\end{array}$} & \multirow{3}{*}{$\begin{array}{l}\text { Confidence } \\
\text { Upper } \\
\text { Bound }\end{array}$} \\
\hline & & & & & & \\
\hline & & & & & & \\
\hline \multirow{5}{*}{ Consumer Staples } & Real Estate & 17.779 & 8.810 & .343 & -8.057 & 43.616 \\
\hline & Services/Insurance & 21.048 & 7.812 & .090 & -1.862 & 43.959 \\
\hline & Industrial & 9.409 & 8.132 & .855 & -14.439 & 33.259 \\
\hline & $\begin{array}{l}\text { Financial Services and } \\
\text { Banks }\end{array}$ & .221 & 7.524 & 1.000 & -21.843 & 22.286 \\
\hline & $\begin{array}{l}\text { Technology and } \\
\text { Telecommunication }\end{array}$ & 14.471 & 11.286 & .794 & -18.626 & 47.568 \\
\hline \multirow{5}{*}{ Real Estate } & Consumer Staples & -17.779 & 8.810 & .343 & -43.616 & 8.057 \\
\hline & Services/Insurance & 3.268 & 6.566 & .996 & -15.988 & 22.526 \\
\hline & Industrial & -8.369 & 6.944 & .833 & -28.734 & 11.995 \\
\hline & $\begin{array}{l}\text { Financial Services and } \\
\text { Banks }\end{array}$ & -17.557 & 6.220 & .066 & -35.801 & .685 \\
\hline & $\begin{array}{l}\text { Technology and } \\
\text { Telecommunication }\end{array}$ & -3.308 & 10.462 & 1.000 & -33.990 & 27.374 \\
\hline \multirow{5}{*}{ Services/Insurance } & Consumer Staples & -21.048 & 7.812 & .090 & -43.959 & 1.862 \\
\hline & Real Estate & -3.268 & 6.566 & .996 & -22.526 & 15.988 \\
\hline & Industrial & -11.638 & 5.625 & .316 & -28.134 & 4.856 \\
\hline & $\begin{array}{l}\text { Financial Services and } \\
\text { Banks }\end{array}$ & -20.826 & 4.702 & .000 & -34.617 & -7.036 \\
\hline & $\begin{array}{l}\text { Technology and } \\
\text { Telecommunication }\end{array}$ & -6.577 & 9.637 & .983 & -34.839 & 21.685 \\
\hline \multirow{5}{*}{ Industrial } & Consumer Staples & -9.409 & 8.132 & .855 & -33.259 & 14.439 \\
\hline & Real Estate & 8.369 & 6.944 & .833 & -11.995 & 28.734 \\
\hline & Services/Insurance & 11.638 & 5.625 & .316 & -4.856 & 28.134 \\
\hline & $\begin{array}{l}\text { Financial Services and } \\
\text { Banks }\end{array}$ & -9.188 & 5.217 & .497 & -24.487 & 6.111 \\
\hline & $\begin{array}{l}\text { Technology and } \\
\text { Telecommunication }\end{array}$ & 5.061 & 9.898 & .996 & -23.966 & 34.090 \\
\hline \multirow{5}{*}{$\begin{array}{l}\text { Financial } \\
\text { Banks }\end{array}$} & Consumer Staples & -.221 & 7.524 & 1.000 & -22.286 & 21.843 \\
\hline & Real Estate & 17.557 & 6.220 & .066 & -.685 & 35.801 \\
\hline & Services/Insurance & 20.826 & 4.702 & .000 & 7.036 & 34.617 \\
\hline & Industrial & 9.188 & 5.217 & .497 & -6.111 & 24.487 \\
\hline & $\begin{array}{l}\text { Technology and } \\
\text { Telecommunication }\end{array}$ & 14.249 & 9.405 & .656 & -13.331 & 41.830 \\
\hline \multirow{5}{*}{$\begin{array}{l}\text { Technology } \\
\text { Telecommunication }\end{array}$} & Consumer Staples & -14.471 & 11.286 & .794 & -47.568 & 18.626 \\
\hline & Real Estate & 3.308 & 10.462 & 1.000 & -27.374 & 33.990 \\
\hline & Services/Insurance & 6.577 & 9.637 & .983 & -21.685 & 34.839 \\
\hline & Industrial & -5.061 & 9.898 & .996 & -34.090 & 23.966 \\
\hline & $\begin{array}{l}\text { Financial Services and } \\
\text { Banks }\end{array}$ & -14.249 & 9.405 & .656 & -41.830 & 13.331 \\
\hline
\end{tabular}

*. The mean difference is significant at the 0.05 level. 


\section{1) Macrothink}

International Journal of Accounting and Financial Reporting

ISSN 2162-3082 2022, Vol. 12, No. 1

The above table (Table 10) reveals that the mean difference of the "Financial Services and Banks" and the "Services/Insurance" sectors is significant at the 1 percent alpha ( $p$ value < 0.01). Hence, the "Financial Services and Banks" sector is proven empirically to have the highest rank in terms of voluntary disclosure score as opposed to other sectors. For instance, there is a 20.82 score difference between "Financial Services and Banks" and "Services/Insurance" industry. These findings do not confirm the ones found in Table 8 where it was observed that the "Consumer Staples" sector ranked the first in terms of mean score. This is due to the low number of consumer staple firms selected in the sample size. The above findings are consistent with the ones of Al-Janadi et al. (2012) and Al-Janadi et al. (2013) that revealed that the voluntary disclosure score mean for the financial sector exceeds the ones of the industrial and the service sector.

The second part here, addresses the results for the factors determining the VDS in the GCC firms. The researchers start with the descriptive results. Table 11 reveals the mean values of all the independent variables selected for model one. The total voluntary disclosure scores ranged between 20 and 84 percent showing an average score of 51 percent. The debt-to-assets ratio ranged between 3 and 91 percent with an average of 49 percent across all firms in the sample size. The following results identified also that the majority of the firms in the GCC chose one of the top four auditing firms. Moreover, the firms' boards in the GCC countries appeared to be relatively independent as indicated by an average proportion of non-executive directors on the board of 84.20 percent. Lastly, the following results have identified that the maximum and minimum return on equity scores were 37.51 and -16.87 percent respectively with a mean score of 9.75 percent. 
Table 11. Descriptive Statistics of the Econometric Model

\begin{tabular}{|c|c|c|c|c|c|c|c|c|c|}
\hline & $\mathrm{N}$ & Minimum & Maximum & Mean & Std. & Skewnes & & Kurtosis & \\
\hline & Statistic & Statistic & Statistic & Statistic & Statistic & Statistic & $\begin{array}{l}\text { Std. } \\
\text { Error }\end{array}$ & Statistic & $\begin{array}{l}\text { Std. } \\
\text { Error }\end{array}$ \\
\hline $\begin{array}{l}\text { Total Voluntary } \\
\text { Disclosure Score }\end{array}$ & 74 & 20.00 & 83.81 & 50.746 & 17.375 & -.085 & .279 & -1.064 & .552 \\
\hline Debt Ratio & 74 & 2.85 & 90.80 & 49.086 & 27.723 & -.034 & .279 & -1.075 & .552 \\
\hline Big Four Auditing Firm & 74 & 0 & 1 & .85 & .358 & -2.016 & .279 & 2.123 & .552 \\
\hline Proportion & & & & & & & & & \\
\hline $\begin{array}{l}\text { Non-Executive Directors } \\
\text { on the Board }\end{array}$ & 74 & .14 & 1.00 & .842 & .235 & -.985 & .279 & 1.201 & .552 \\
\hline ROE & 74 & -16.87 & 37.51 & 9.75 & 10.22 & -.466 & .279 & .720 & .552 \\
\hline Consumer Staples Sector & 74 & 0 & 1 & .07 & .253 & 3.517 & .279 & 10.659 & .552 \\
\hline Real Estate Sector & 74 & 0 & 1 & .11 & .313 & 2.577 & .279 & 4.767 & .552 \\
\hline Services/Insurance Sector & 74 & 0 & 1 & .24 & .432 & 1.222 & .279 & -.522 & .552 \\
\hline Industrial Sector & 74 & 0 & 1 & .16 & .371 & 1.871 & .279 & 1.542 & .552 \\
\hline $\begin{array}{l}\text { Financial Services \& } \\
\text { Banks Sector }\end{array}$ & 74 & 0 & 1 & .38 & .488 & .512 & .279 & -1.787 & .552 \\
\hline Technology & & & & & & & & & \\
\hline Telecommunication & 74 & 0 & 1 & .04 & .199 & 4.756 & .279 & 21.194 & .552 \\
\hline Sector & & & & & & & & & \\
\hline Valid N (listwise) & 74 & & & & & & & & \\
\hline
\end{tabular}

Pearson correlation analysis between the overall voluntary disclosure score and its independent variables. The results reveal that the overall voluntary disclosure score is positively correlated with the firm's return-on-equity (ROE) $(\mathrm{r} 0.287 p<0.05)$ and significant at the 0.05 alpha. Hence, higher ROE ratios are associated with higher disclosure scores. Furthermore, it was evidenced that the voluntary disclosure scores in the GCC are positively and significantly correlated with the firm's leverage (r $0.277 p<0.05)$ at the 0.05 alpha. The findings prove empirically that higher leverage position is associated with higher disclosure scores. This appears to be reasonable as companies with higher leverage positions tend to disclose more information to satisfy creditors.

\subsection{Determinants of Voluntary Disclosures in the GCC Firms}

The following model represents the determinants of voluntary disclosures in the GCC countries. Based on the results of the ANOVA test, all the industry variables were discarded except for the significant ones.

$$
\begin{aligned}
\operatorname{VDS}_{\mathrm{t}, \mathrm{i}}= & \beta_{0}+\beta_{1} \mathrm{ROE}_{\mathrm{t}, \mathrm{i}}+\beta_{2} \mathrm{DR}_{\mathrm{t}, \mathrm{i}}+\beta_{3} \mathrm{BFAF}_{\mathrm{t}, \mathrm{i}}+\beta_{4} \mathrm{Bind}_{\mathrm{t}, \mathrm{i}}+\beta_{5} \mathrm{IND}_{\mathrm{i}, \mathrm{RE}}+\beta_{6} \mathrm{IND}_{\mathrm{i}, \mathrm{S} / \mathrm{I}}+\beta_{7} \mathrm{IND}_{\mathrm{i}} \\
& \mathrm{FSB}+\varepsilon
\end{aligned}
$$

Where:

t: The year of study 
$\mathrm{i}$ : The $\mathrm{i}^{\text {th }}$ firm selected

$\varepsilon:$ The error term

A summary of the regression results is demonstrated in the following tables. Table 12 shows the adjusted $\mathrm{R}$ square of the first econometric model and indicates that 34 percent of the variation in the dependent variable (voluntary disclosure score) is explained by the variation of the independent variables.

Table 12. Explanatory Power of Econometric Model

\begin{tabular}{|c|c|c|c|c|}
\hline Model & $\mathrm{R}$ & R Square & Adjusted R Square & $\begin{array}{l}\text { Std. Error of the } \\
\text { Estimate }\end{array}$ \\
\hline
\end{tabular}

1 $.583^{\mathrm{a}}$ .340 .281 14.7320961

a. Predictors: (Constant), Financial Services \& Banks Sector, ROE, Big Four Auditing Firm, Real Estate Sector, Debt Ratio, Services/Insurance Sector

Table 13. ANOVA Output of Econometric Model

\begin{tabular}{lllllll}
\hline Model & & Sum of Squares & df & Mean Square & F & Sig. \\
\hline \multirow{3}{*}{1} & Regression & 7497.199 & 6 & 1249.533 & 5.757 & $.000^{\mathrm{b}}$ \\
& Residual & 14541.322 & 67 & 217.035 & & \\
& Total & 22038.521 & 73 & & & \\
\hline
\end{tabular}

a. Dependent Variable: Total Voluntary Disclosure Score

b. Predictors: (Constant), Financial Services and Banks, Big Four Auditing Firm. Proportion of Non-Executive Directors on the Board, Services/Insurance Sector, Debt Ratio, Real Estate Sector, ROE

The above table (Table 13) identifies that the $\mathrm{F}_{\text {STAT }}$ value is $5.757(p<0.01)$. This shall fully support the significance of the regression model proving empirically that all the coefficients are different from zero.

The results of the regression are shown in Table 19. The coefficient of leverage (Debt Ratio) is statistically significant at the 5 percent alpha $(p<0.05)$ which indicates that the null hypothesis (H2) is rejected; hence, its alternate is proved to be true and the firm's leverage is positively associated with its level of voluntary disclosure. The coefficients representing the "Real Estate" and "Service/Insurance" industries were also significant at the 5 and 1 percent alpha respectively ( $p$-value $<0.05 ; p$-value $<0.01$ ), such a finding shows that the null hypothesis (H4) is rejected, and thus economic sectors differ in their voluntary disclosure score. The remaining variables were insignificant even at the 10 percent alpha. Until this part of the analysis, the remaining null hypotheses $(\mathrm{H} 1, \mathrm{H} 3$, and $\mathrm{H} 5)$ are true and hence they cannot be rejected; so, profitability, the type of auditing firms, and board independence do not appear to have any positive impact on voluntary disclosure. 


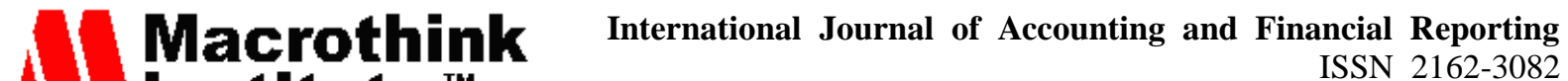 2022, Vol. 12, No. 1}

Table 14. Results of Econometric Model Coefficients ${ }^{\mathrm{a}}$

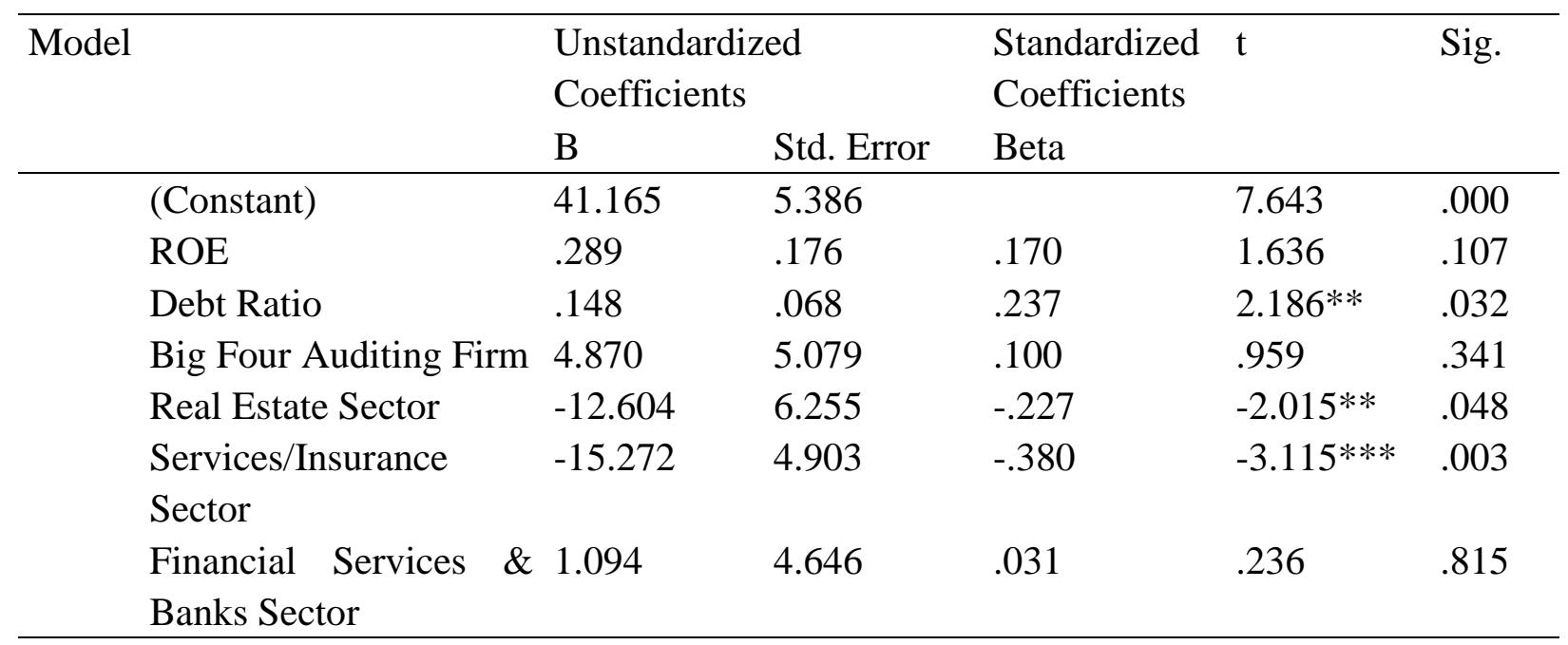

a. Dependent Variable: Total Voluntary Disclosure Score

b. *. Variable is significant at the 0.10 level (2-tailed).

**. Variable is significant at the 0.05 level (2-tailed)

***. Variable is significant at the 0.01 level (2-tailed).

\subsection{Discussion of the Results}

Profitability. The empirical evidence derived from Table 14 shows that that there is no significant relation between the voluntary disclosure score of a firm and its profitability (ROE) level ( $p$-value $>0.10)$. The univariate and multivariate tests here have produced contradictory results. With reference to Table 10, there is a significant relation between the voluntary disclosure score and the firm's ROE. Nevertheless, this was completely refuted when testing for the significance of the ROE coefficient. Hence, there is no empirical evidence to reject the null hypothesis of firm's profitability being not positively associated with its level of voluntary disclosures.

This result fully supports the findings of Larran and Giner (2002), Oyelere et al. (2003), Marston and Polei (2004), Xiao et al. (2004), Momany and Al-Shorman (2006), Ezat and Al-Masry (2008), and Charumathi and Ramesh (2015) when they found out that there is no significant relation between the above two variables. Though, Hossain (2008), Cheung et al. (2010), and Omar and Simon (2011) succeeded to determine a significant relation between the two variables.

Leverage. The variable of leverage (Debt Ratio) is positively significant at the 5 percent alpha ( $p$-value $<0.05)$ with firm's voluntary disclosure score. This relation appears to be reasonable as companies tend to disclose more information with more levels of leverage. Hence, there is empirical evidence to reject the null hypothesis of firm's leverage not being positively associated with its level of voluntary disclosures.

This result fully supports the findings of Robbins et al. (1986), karim et al. (2005), Bruslerie et al. (2010), and Omar et al. (2011). On the other hand, it contradicts completely the findings 
of Ezat and El-Masry (2008), Al-Shammari and Al-Sultan (2010), and Basuony and Mohamed (2014) when they failed to identify a significant relationship between the firm's leverage position with its voluntary disclosure score.

Audit type. With reference to Table 14, the results point out that the "Type of Auditing Firm" is not a significant factor that impacts the firm's voluntary disclosures score ( $p$-value $>0.10$ ). Still, there is no empirical evidence to conclude that the type of auditing firm is a significant factor that impacts the firm's voluntary disclosure score.

The above results were consistent with previous studies such as Wallace et al. (1994), Hossain et al. (1995), Abd El Salam (1999), Al-Shammari et al. (2010), Basuony and Mohamed (2014), and Charumathi and Ramesh (2015) when they did not detect any significant relation between the type of auditing firms and the firm's disclosure level. On the other hand, the above result contradicted the findings of Ahmed and Nicholls (1994), Raffournier (1995), Xiao et al. (2004), Uyar et al. (2013), and Al-Janadi et al. (2013) when they succeeded to determine a significant relation between these two variables.

Board independence. The board's Independence, as measured by the proportion of the non-executive directors out of the total board size, appeared to be insignificant with the firm's voluntary disclosure score ( $p$-value $>0.10)$. This is due to the nature of selecting these non-executive directors in the GCC countries. They are selected because of their contacts regardless of their credentials and experience. This shall not lead to independent monitoring. As a result, there is no empirical evidence to reject the null hypothesis.

The above result was consistent with previous studies such as Minguez and Martin (2003), Carter et al. (2010), Al-Shammari and Al-Sultan (2010), and Charamuthi and Ramesh (2015) when they concluded that the board's independence does not explain the variation in the firm's voluntary disclosure score. Yet, other studies such as Osma (2008), Ghosh et al. (2010), Azim (2012), Uyar et al. (2013), and Chang et al. (2015) proved empirically that the board's independence impacts positively the firm's voluntary disclosure score.

Furthermore, the findings of the Real Estate Sector were consistent with the results of Al-Shammari and Al-Sultan (2010) in Kuwait when they have found out that the latter sector is statistically significant at the 1 percent alpha. As for the Insurance/Services Sector, the results contradicted the findings of Al-Shammari and Al-Sultan (2010) and Al-Janadi et al. (2013) as both studies failed to identify a significant relationship between the type of sector and the firm's level of voluntary level.

Both the ANOVA results and the econometric output jointly identified that the Services/Insurance sector is statistically significant at the 1 percent alpha. As a result of its strong statistical significance, a new version of econometric model one (B) is created by adding an interaction term between the ROE variable and the type of sector. Henceforth, "ROESI" and "ROEXSI" represent two additional explanatory variables that were added to model one (B) in order to distinguish between the ROE of the Services/Insurance sector (ROESI) and the ones of all other sectors (ROEXSI). In an attempt to capture their joint interaction, the results of Table 15 revealed that there a statistical significant interaction 


\section{Mll Macrothink}

International Journal of Accounting and Financial Reporting

ISSN 2162-3082

between ROE and all other sectors ( $p$-value < 0.10) except for the Services/Insurance sector. This shall also be explained by the difference in the unstandardized coefficients of ROESI and ROEXSI variables. The ROESI has a negative coefficient of -0.181 which denotes that the ROEs of the Services/Insurance sector are contributing negatively to the firm's voluntary disclosure score. Plus, this clearly identifies that the ROESI does not explain the variation in the firm's voluntary disclosure level unlike the ROEXSI. A possible explanation of this finding is that this sector was the least transparent one. Another explanation might be that the ROE mean for Services/Insurance sector (1.9\%) is lower than the one of all other sectors (7.9\%).

Table 15. Explanatory Power of Econometric Model One (B).

\begin{tabular}{llllll}
\hline Model & $\mathrm{R}$ & R Square & Adjusted R Square & $\begin{array}{l}\text { Std. Error of the } \\
\text { Estimate }\end{array}$ \\
\hline 1 & $.618^{\mathrm{a}}$ & .382 & .316 & 14.3694695 & \\
\hline
\end{tabular}

a. Predictors: (Constant), ROEXIS, Proportion of Non-Executive Directors on the Board, Real Estate Sector, Debt Ratio, Big Four Auditing Firm, ROEIS, Services/Insurance Sector

Table 16. ANOVA Output of Econometric Model One (B)

\begin{tabular}{lllllll}
\hline \multirow{2}{*}{ Model } & & $\begin{array}{l}\text { Sum } \\
\text { Squares }\end{array}$ & of Df & $\begin{array}{l}\text { Mean } \\
\text { Square }\end{array}$ & F & Sig. \\
\hline \multirow{4}{*}{1} & Regression & 8410.731 & 7 & 1201.533 & 5.819 & $.000^{\mathrm{b}}$ \\
& Residual & 13627.789 & 66 & 206.482 & & \\
& Total & 22038.521 & 73 & & & \\
\hline
\end{tabular}

a. Dependent Variable: Total Voluntary Disclosure Score

b. Predictors: (Constant), ROEXIS, Proportion of Non-Executive Directors on the Board, Real Estate Sector, Debt Ratio, Big Four Auditing Firm, ROEIS, Services/Insurance Sector

The results of Table 17 reveal version B of econometric model one demonstrating that there is an additional significant variable in the model with an improvement in the explanatory power. 
Table 17. Results of Econometric Model One (B)

\begin{tabular}{|c|c|c|c|c|c|}
\hline \multirow[t]{2}{*}{ Model } & \multicolumn{2}{|c|}{$\begin{array}{l}\text { Unstandardized } \\
\text { Coefficients }\end{array}$} & \multirow{2}{*}{$\begin{array}{l}\text { Standardized } \\
\text { Coefficients } \\
\text { Beta }\end{array}$} & \multirow[t]{2}{*}{$\mathrm{t}$} & \multirow[t]{2}{*}{ Sig. } \\
\hline & $\mathrm{B}$ & Std. Error & & & \\
\hline (Constant) & 44.792 & 7.662 & & 5.846 & .000 \\
\hline Debt Ratio & .153 & .063 & .244 & $2.436 * *$ & .018 \\
\hline ROEIS & -.181 & .286 & -.072 & -.634 & .528 \\
\hline ROEXIS & .505 & .212 & .271 & $2.388 * *$ & .020 \\
\hline Services/Insurance Sector & -9.871 & 5.071 & -.245 & $-1.947 * *$ & .056 \\
\hline Big Four Auditing Firm & 5.922 & 5.014 & .122 & 1.181 & .242 \\
\hline Proportion of Non-Executive & -7.659 & 7.428 & -.104 & -1.031 & .306 \\
\hline $\begin{array}{l}\text { Directors on the Board } \\
\text { Real Estate Sector }\end{array}$ & -12.773 & 5.522 & -.230 & $-2.313 * *$ & .024 \\
\hline
\end{tabular}

a. Dependent Variable: Total Voluntary Disclosure Score

b. *. Variable is significant at the 0.10 level (2-tailed).

**. Variable is significant at the 0.05 level (2-tailed)

$* * *$. Variable is significant at the 0.01 level (2-tailed).

After discarding all the insignificant variables, Tables 18, 19, and 20 show the final version of econometric model one $(\mathrm{C})$. The results prove that that there is an improvement of 2.1 percent in the explanatory power in addition to a stronger statistical significance of the model showing an $\mathrm{F}_{\text {STAT }}$ of 9.763 ( $p$-value $\left.<0.01\right)$.

Table 18. Explanatory Power of Econometric Model One (C)

\begin{tabular}{lcclc}
\hline Model & $\mathrm{R}$ & $\mathrm{R}$ Square & $\begin{array}{l}\text { Adjusted } \\
\text { Square }\end{array}$ & $\begin{array}{c}\mathrm{R} \\
\text { Std. Error of } \\
\text { the Estimate }\end{array}$ \\
\hline 1 & $.601^{\mathrm{a}}$ & .361 & .324 & 14.2815155 \\
\hline
\end{tabular}

Table 19. ANOVA Output of Econometric Model One (C)

\begin{tabular}{lllllll}
\hline \multirow{2}{*}{ Model } & & $\begin{array}{l}\text { Sum } \\
\text { Squares }\end{array}$ & of Df & $\begin{array}{l}\text { Mean } \\
\text { Square }\end{array}$ & F & Sig. \\
\hline & & & & & & \\
\hline \multirow{2}{*}{1} & Regression & 7965.164 & 4 & 1991.291 & 9.763 & $.000^{\mathrm{b}}$ \\
& Residual & 14073.356 & 69 & 203.962 & & \\
& Total & 22038.521 & 73 & & & \\
\hline
\end{tabular}

a. Dependent Variable: Total Voluntary Disclosure Score

b. Predictors: (Constant), ROEXIS, Real Estate Sector, Debt Ratio, Services/Insurance Sector

Besides the slight improvement in the explanatory power, Table 4.20 presents the final result of model one showing that the Debt Ratio and ROEXIS are statistically significant at the 1 percent alpha ( $p$-value < 0.01). Besides, the Real Estate Sector and Services/Insurance Sector 


\section{Macrothink}

International Journal of Accounting and Financial Reporting

ISSN 2162-3082

2022, Vol. 12, No. 1

are statistically significant at the 5 percent alpha ( $p$-value < 0.05 ). Hence, $\mathrm{H} 1$ in the modified econometric model is false and ROE has a positive association with the level of voluntary disclosure after having excluded the services/insurance sector.

Table 20. Results of Econometric Model One (C)

\begin{tabular}{llllll}
\hline \multirow{2}{*}{ Model } & \multicolumn{2}{l}{$\begin{array}{l}\text { Unstandardized } \\
\text { Coefficients }\end{array}$} & \multicolumn{2}{l}{$\begin{array}{l}\text { Standardized } \\
\text { Coefficients }\end{array}$} & S \\
& B & Std. Error & Beta & \\
\hline (Constant) & 42.452 & 4.099 & & 10.357 & .000 \\
Debt Ratio & .163 & .061 & .260 & $2.665^{* * *}$ & .010 \\
ROEXIS & .549 & .207 & .294 & $2.647 * * *$ & .010 \\
Services/Insurance Sector & -10.627 & 4.515 & -.264 & $-2.354^{* *}$ & .021 \\
Real Estate Sector & -13.250 & 5.470 & -.238 & $-2.423^{* *}$ & .018 \\
\hline
\end{tabular}

Dependent Variable: Total Voluntary Disclosure Score

*. Variable is significant at the 0.10 level (2-tailed).

**. Variable is significant at the 0.05 level (2-tailed)

***. Variable is significant at the 0.01 level (2-tailed).

To check the robustness of the findings, two subsets of the database were arranged by country and sector. The first subset included only the three largest countries represented in the sample which are Kuwait, KSA, and the UAE. The results of the first subset were slightly similar to the ones reported previously except for the debt ratio and real estate sector which are now significant at the 10 percent alpha ( $p$-value $<0.10)$. As for the second subset, it included only the three sectors that are essentially contributing to the sample size which are the "Financial Services \& Banks", "Real Estate", and "Services/Insurance". The results were consistent with ones reported previously except for the ROEXIS variables which appeared to be insignificant in explaining the variation in the voluntary disclosure scores. 


\section{Mll Macrothink}

International Journal of Accounting and Financial Reporting

Table 21. Robustness Test Output

\begin{tabular}{lll}
\hline & Sub-VDS (1) & Sub-VDS (2) \\
& 3 Countries Only & 3 Sectors Only \\
& Kuwait, KSA, UAE & Financial, S/I, Real Estate \\
\hline \multirow{2}{*}{ Debt Ratio } & $0.153^{*}$ & $0.166^{* *}$ \\
ROEIS & {$[0.073]$} & {$[0.038]$} \\
& -0.240 & -0.207 \\
ROEXIS & {$[0.414]$} & {$[0.502]$} \\
& $0.645^{* *}$ & 0.476 \\
Service/Insurance Sector & {$[0.017]$} & {$[0.148]$} \\
& $-12.489^{* *}$ & $-10.341^{*}$ \\
Big Four Auditing Firm & {$[0.037]$} & {$[0.098]$} \\
& 6.968 & 4.302 \\
Board Independence & {$[0.235]$} & {$[0.549]$} \\
& -4.821 & -12.123 \\
Real Estate sector & {$[0.652]$} & {$[0.237]$} \\
Intercept & $-10.97 *$ & $-13.579^{* *}$ \\
Observations & {$[0.058]$} & {$[0.033]$} \\
R-square & $38.628^{* * *}$ & $50.145^{* * *}$ \\
F-test & {$[0.001]$} & {$[0.000]$} \\
\hline
\end{tabular}

$*, * *, * * *$ indicate statistical significance at 10,5 , and 1 percent levels respectively. $P$-values are reported in parentheses.

\section{Conclusions}

\subsection{Conclusions}

This research work pursued the investigation of the transparency level of a number of listed corporations in the GCC and the degree of voluntary disclosures in the annual reports of the fiscal year 2015. It aimed as well to determine the determinants of voluntary disclosures in GCC countries. A sample of 74 is selected from a population of 811 firms listed in the six GCC countries. A voluntary disclosure index containing 44 voluntary information items of data was used to assign a voluntary disclosure score for every firm selected in the sample size.

The scoring results identified that there is a variation in the voluntary disclosure score of every firm with 47 percent of the sample size ( 35 firms) scoring below 50 percent. The scores also detected that the firms were doing extremely well, in terms of transparency, on the "Background", "Corporate Strategy", "General Risk Management", and "Accounting Policy Review" categories as they are imposed by their local laws and international financial reporting standards. Likewise, the results also proved that GCC firms are not relatively transparent on 


\section{Macrothink}

International Journal of Accounting and Financial Reporting

ISSN 2162-3082

2022, Vol. 12, No. 1

"Corporate Governance", "Financial Performance", and "Corporate Social Disclosure". The final results pinpointed that the average voluntary disclosure score of the 74 firms is 51 percent. Furthermore, the results showed that the country of Oman was the most transparent as opposed to other GCC countries followed by Qatar, Bahrain, Kuwait, UAE and KSA. The results revealed as well that the "Financial Services and Banks" sector is proven empirically to rank the first in terms of voluntary disclosure score as opposed to other sectors.

Moving to the univariate analysis of the models, the firm's voluntary disclosure score was found to be significantly and statistically correlated with its return-on-equity (ROE), debt-to-assets ratio, and the number of board meetings held per annum. The econometric model one created in order to determine the determinants of voluntary disclosures in the GCC countries, concluded that the debt-to-assets ratio ( $p$-value $<0.05)$, real estate sector $(p$-value < $0.05)$, and services/insurance sector ( $p$-value $<0.05)$ with the model being statistically significant with an $\mathrm{F}_{\mathrm{STAT}}$ of 4.741 ( $p$-value $<0.01$ ). It also identified that the return-on-equity explains the variation in the firms' voluntary disclosures for all sectors except those belonging to the services/insurance sector. This also explains why the services/insurance sector ranked the least in terms of transparency.

The results of this paper might be of great use for all those who want to investigate further the transparency level in every country. Moreover, this study will be also used as a main reference for new studies willing to explore on a comparative basis the transparency level of the six middle-eastern countries.

\subsection{Recommendations.}

Based on the results of this paper, the researchers recommend companies to increase and enhance the quality of voluntary disclosures in their annual reports to encompass useful information for decision-making as well as to enhance their connections with their stakeholders via an active "Investor's Relations" section on their corporate website.

Moving to future research opportunities, the authors recommend repeating the same research framework using more than the corporate annual report as a source of voluntary disclosures as well as drafting a research framework that applies exclusively on each sector and each country found in the GCC.

\subsection{Limitations of the Study}

The research work faced many technical limitations: for instance, the researchers acknowledge that relying solely on Annual Reports of 2015 is not enough. The work would have been more valuable if it was carried out over several periods. Moreover, the excessive reliance on the annual reports and disregarding the other disclosure platforms is another limitation. Furthermore, some GCC companies had only Arabic annual reports posted on their websites. Finally, the passiveness of the "Investor Relations" contact people who were disregarding the researchers' attempt for collecting data and they did not even acknowledge the receipt of the sent-out email. 


\section{$\Lambda$ Macrothink}

International Journal of Accounting and Financial Reporting

ISSN 2162-3082

2022, Vol. 12, No. 1

\section{References}

Abd El Salam, O. H. (1999). The Introduction and Application of International Accounting Standards to Accounting Disclosure Regulations of a Capital Market in Developing Country: The Case of Egypt. PhD thesis, Heriot-Watt University, Edinburgh.

Adawi, M., \& Rwegasira, K. (2011). Corporate boards and voluntary implementation of best disclosure practices in emerging markets: Evidence from the UAE listed companies in the Middle East. International Journal of Disclosure and Governance, 8(3), 272-293.

Ahmed, K., \& Nicholls, D. (1994). The Impact of non-financial Company Characteristics on Mandatory Disclosure Compliance in Developing Countries: The Case of Bangladesh. The International Journal of Accounting, 29, 62-77.

Akhtaruddin, M. (2005). Corporate mandatory disclosure practices in Bangladesh. International Journal of Accounting, 40, 399-422.

Aksu, M., \& Kosedag, A. (2006). Transparency and Disclosure Scores and their Determinants in the Istanbul Stock Exchange. Blackwell Journal Compilation, 14(4), 277-295.

Al Mamun, S. A., \& Kamardin, H. (2014). Corporate Voluntary Disclosure Practices of Banks in Bangladesh. Procedia - Social and Behavioral Sciences, 164, 258-263. https://doi.prg/10.1016/j.sbspro.2014.11.075

Al-Janadi, Y., Abdul Rahman, R., \& Haj Omar, N. (2013). Corporate Governance Mechanisms and Voluntary Disclosure in Saudi Arabia. Research Journal of Finance and Accounting, 4(4), 25-35.

Al-Janadi, Y., Rahman, R., \& Omar, N. (2012). The level of voluntary disclosure practices among public listed companies in Saudi Arabia and the UAE: Using a modified voluntary disclosure index. Int J Discl Gov, 9, 181-201. https://doi.org/10.1057/jdg.2011.19

Al-Shammari, \& Al-Sultan. (2010). International Journal of Disclosure and Governance, $7(3), 274$.

Al-Shattarat, W. K., Haddad, A. E., \& Al-Hares, O. M. (2010). The extent of voluntary disclosure in an emerging capital market: The case of Jordan. Journal of Modern Accounting and Auditing, 6(10), 39-51.

Aly, D., Simaon, J., \& Hussainey, K. (2009). Determinants of CIR: Evidence from Egypt. Managerial Auditing Journal, 25(2), 182-202.

Arcay, M., \& Vasquez, M. (200). Corporate Characteristics of Governance Rules and the Extent of Voluntary Dislosure in Spain. Advances in Accounting, 21, 299-331.

Ashbaugh, H., Johnstone, K., \& Warfield, T. (1999). Corporate Reporting on the Internet. Accounting Horizons, 13(3), 241-257.

Azim, M. I. (2012). Corporate governance mechanisms and their impact on company performance: a structural equation model analysis. Aust. J. Manage, 37, 481-505. 


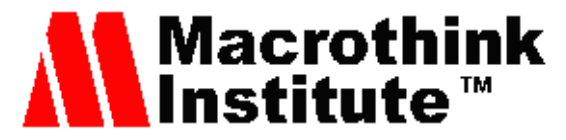

International Journal of Accounting and Financial Reporting ISSN 2162-3082

Barako, D. G., Hancock, P., \& Izan, H. Y. (2006). Factors Influencing Voluntary Corporate Disclosure by Kenyan Companies. Journal Compilation, 14(2), 107-125.

Barett, M. E. (1977). The extent of disclosure in annual report of large companies in seven countries. The International Journal of Accounting, 13(2), 1-25.

Basuony, M. A. K., \& Mohamed, E. K. A. (2014). Determinants of Internet Financial Disclosure in GCC Countries. Asian Journal of Finance and Accounting, 6(1), 70-89.

Baydoun, N., Maguire, W., Ryan, N., \& Willet, R. (2013). Corporate Governance in Five Arabian Gulf Countries. Managerial Auditing Journal, 28, 7-22.

Berle, A., \& Means, G. (1932). The Modern Corporation and Private Property. Transaction Publishers, New York, NY.

Bollen, L., Hassink, H., \& Bozic, G. (2006). Measuring and Explaining the Quality of Internet Investor Relations Activities: A Multinational Empirical Analysis. International Journal of Accounting Information Systems, 7, 273-298.

Bonsonn, E., \& Escobar, T. (2002). A Survey on Voluntary Disclosure on the Internet: Empirical Evidence from 300 European Union Companies. The International Journal of Accounting Research, 2(1), 27-51.

Boubaker, S., Lakhal, F., \& Nekhili, M. (2012). The Determinants of Web-based Corporate Reporting in France. Managerial Auditing Journal, 27(2), 126-155.

Brennan, N., \& Hourigan, D. (2000). Corporate Reporting on the Internet by Irish Companies. Accountancy Ireland, 30(6), 18-21.

Bruslerie, H., \& Gabteni, H. (2010). Voluntary Financial Disclosure, Introduction of IFRS and the setting of a Communication Policy: An Empirical Test on SBF French Firms using a Publication Score. Multinational Financial Society, Barcelona: Espagne.

Bryman, A. (2006). Integrating Quantitative and Qualitative Research: How is it done?. Qualitative Research, 6(1), 97-113.

Buzby, S. L. (1972). An Empirical Investigation of the Relationship between the Extent of Disclosure. An unpublished doctoral dissertation, Pennsylvania State University.

Cerf, A. R. (1961). Corporate Reporting and Investment Decisions. University of California, Berkeley.

Chang, C. S., Yu, S. W., \& Hung, C. H. (2015). Firm risk and performance: The role of corporate governance. Rev. Manag. Sci, 9, 141-173.

Charumathi, B., \& Ramesh, L. (2015). On the Determinants of Voluntary Disclosure by Indian Companies. Asia-Pacific Journal of Management Research and Innovation, 11(2), 108-116.

Chen, C. J. P., \& Jaggi, B. (2000). Association between independent non-executive directors, family control and financial disclosure in Hong Kong. Journal of Accounting and Public Policy, 19, 285-310. 


\section{MInstitute ${ }^{\text {Mink }}$}

International Journal of Accounting and Financial Reporting ISSN 2162-3082

Cheung, Y. L., Jiang, P., Limpaphayom, P., \& Lu, T. (2010). Corporate governance in China: A step forward. European Financial Management, 16, 94-123.

Choi, F. D. S., \& Hiramatsu, K. (1987). Accounting and Financial Reporting in Japan. Wokingham: Van Nostrand Reinhold, UK.

Chow, C., \& Boren, A. (1987). Voluntary financial disclosure by Mexican corporations. The Accounting Review, 52(3), 533-541.

Cooke, T. E. (1989). Disclosure in the corporate annual reports of Swedish companies. Accounting and Business Research, 19(74), 113-124.

Cooke, T. E. (1991). An Assessment of Voluntary Disclosure in the Annual Reports of Japanese Corporations. The International Journal of Accounting Education and Research, 26, 174-189.

Cooke, T. E. (1992). The Impact of Size, Stock Market Listing and Industry Type on Disclosure in the Annual Reports of Japanese Listed Corporations. Accounting and Business Research, 22(87), 229-237.

Copeland, R. M., \& Fredericks, M. (1968). Extent of Disclosure. Journal of Accounting Research, 6(1), 106-113.

Courtis, J. K. (1978). Annual report disclosure in New Zealand: Analysis of selected corporate attribute. New England Accounting Research Study, 8.

DeAngelo, L. (1981). Auditor Size and Audit Quality, Journal of Accounting and Economics, 3, 183-199.

Debreceny, R., \& Rahman, A. (2005). Firm-specific Determinants of Continuous Corporate Disclosure. The International Journal of Accounting, 40, 249-278.

Debreceny, R., Gray, G., \& Rahman, A. (2002). The Determinants of Internet Financial Reporting. Journal of Accounting and Public Policy, 21(4/5), 371-394.

Dyczkowska, J. (2014). Assessment of Quality of Internet Financial Disclosures using a Scoring System. A Case of Polish Stock Issuers. Accounting and Management Information Systems, 13(1), 50-81.

El-Gazzar, S., Fornaro, J., \& Jacob, R. (2008). An examination of the determinants and contents of corporate voluntary disclosure of management's responsibilities for financial reporting. Journal of Accounting, Auditing and Finance, 23(1), 95-114.

Elliott, R. K., \& Jacobson, P. D. (1994). Cost and benefits of business information disclosure. Accounting Horizons, 8(4), 80-96.

Eng, L. L., \& Mak, Y. T. (2003). Corporate governance and voluntary disclosure. Journal of Accounting and Public Policy, 22, 325-345.

Ezzat, A., \& Al-Masry, A. (2008). The Impact of Corporate Governance on the Timeliness of Corporate Internet Reporting by Egyptian listed Companies. Managerial Finance, 34(12), 848-867. 


\section{Macrothink}

International Journal of Accounting and Financial Reporting ISSN 2162-3082

Francis, B. B., Hasan, I., \& Wu, Q. (2012). Do corporate boards matter during the current financial crisis?. Rev. Financ. Econ., 21, 39-52.

Ghazali, N., \& Weetman, P. (2006). Perpetuating Traditional Influences: Voluntary Disclosure in Malaysia Following the Economic Crisis. Journal of International Accounting, Auditing \& Taxation, 15, 226-248.

Haniffa, R. M., \& Cooke, T. E. (2002). Culture, Corporate Governance and Disclosure in Malaysian corporations. Abacus, 38(3), 317-349.

Healy, P. M., Hutton, A., \& Palepu, K. G. (1999). Stock performance and intermediation changes surrounding sustained increases in disclosure. Contemporary Accounting Research, $16,485-520$.

Hossain, M. A. (2000). Disclosure of Financial Information in Developing Countries: A comparative Study of Non-Financial Companies in India, Pakistan and Bangladesh. Doctoral Dissertation, The University of Manchester, UK.

Hossain, M., \& Hammami, H. (2009). Voluntary disclosure in the annual reports of an emerging country: the case of Qatar. Advances in Accounting, Incorporating Advances in International Accounting, 25(2), 255-265.

Hossain, M., Perera, M. H. B., \& Rahman, A. R. (1995), "Voluntary disclosure in annual reports of New Zealand companies. Journal of International Financial Management and Accounting, 6, 69-85.

Hossain, M., Tan, L. M., \& Adams, M. (1994). Voluntary disclosure in an emerging capital market: Some empirical evidence from companies listed on the Kuala Lumpur Stock Exchange. The International Journal of Accounting, 29, 334-351.

Hussainey, K., \& Walker, M. (2009). The Effects of Voluntary Disclosure and Dividend Propensity on Prices leading earnings. Accounting and Business Research, 39(1), 37-55.

Jensen, M., \& Meckling, W. (1976). Theory of the firm: managerial behavior, agency costs and ownership structure. Journal of Financial Economics, 3, 305-360.

Karim, A. K. M. W., \& Ahmed, J, U. (2005). Determinants of IAS Disclosure Compliance in Emerging Economies: Evidence from exchange-listed companies in Bangladesh. Working Paper, no. 21, Victoria University of Wellington.

Karim, R. A. A. (1995). The Nature and Rationale of a Conceptual Framework for Financial Reporting by Islamic Banks. Accounting and Business Research, 25(100), 285-300.

Kolsi, M. C. (2012). The Determinants of Voluntary Corporate Disclosure: Evidence from the Tunisian Capital Market. The UIP Journal of Accounting Research and Audit Practices, 11(4), 49-68.

Laksmana, I. (2008). Corporate Board Governance and Voluntary Disclosure of Executive Compensation Practices. Contemporary Accounting Research, 25, 1147-1182. https://doi.org/10.1506/car.25.4.8 


\section{MInstitute Macrothink $^{\text {Int }}$}

International Journal of Accounting and Financial Reporting ISSN 2162-3082

Larran, M., \& Giner, B. (2002). The Use of the Internet for Corporate Reporting by Spanish Companies. The International Journal of Digital Accounting Research, 2(3), 53-82.

Leftwich, R. (1981, March). Evidence of the Impact of Mandatory Changes in Accounting Principles of Corporate Loan Agreements. Journal of Accounting and Economics, 3-36.

Leventis, S., \& Weetman, P. (2004). Voluntary disclosures in an emerging capital market: some evidence from the Athens stock exchange. Advances in International Accounting, 17, 227-250.

Lincoln, J. R., \& Kalleberg, A. L. (1990). Culture, Control and Commitment. Cambridge: Cambridge University Press.

Malone, D., Fries, C., \& Jones, T. (1993). An empirical investigation of the extent of corporate financial disclosure in the oil and gas industry. Journal of Accounting, Auditing and Finance, 8(3), 249-73.

Mangel, R., \& Singh, H. (1993). Ownership structure, board relationships and CEO compensation in large U.S. corporations. Accounting and Business Research, 23, 339-350.

Meek, G. K., Roberts, C. B., \& Gray, S. J. (1995). Factors influencing voluntary annual report disclosures by US, UK and Continental European multinational corporations. Journal of International Business Studies, 26(3), 555-572.

Mínguez, A., \& Martin, J. F. (2003). The Board of Directors as a Control Mechanism: Evidence for the Spanish Market. Valencian Institute of Economic Research. Retrieved from www.ivie.es

Mitchell, J. D., Chia, C. W. L., \& Loh, A. S. (1995). Voluntary disclosure of segment information: Further Australian evidence. Accounting and Finance, 35, 1-15.

Naser, K., \& Nuseibeh, R. (2003). Users' Perceptions of corporate reporting: evidence from Saudi Arabia. The British Accounting Review, 35, 129-153.

Neu, D., Warsame, H., \& Pedwell, K. (1998). Managing public impressions: environmental disclosures in annual reports. Accounting, Organizations and Society, 23(3), 265-282.

Omar, B., \& Simon, J. (2011). Corporate Aggregate Disclosure Practice in Jordan. Advances in Accounting incorporating Advances in International Accounting, 27, 166-186.

Osma, B. G. (2008). Board independence and real earnings management: the case of R\&D expenditure. Corp. Gov., 16(2), 116-131.

Oyelere, P., Laswad, F., \& Fisher, R. (2003). Determinants of Internet Financial Reporting by New Zealand Companies. Journal of International Financial Management and Accounting, 14(1), 21-63.

Patel, S. A., Dallas, G. S. (2002). Transparency and Disclosure: Overview of Methodology and Study Results - United States. SSRN. https://doi.org/10.2139/ssrn.422800

Popova, T. T., Georgakopoulos, G., Sotiropoulos, I., \& Vasileiou, K. Z. (2013). Mandatory disclosure and its impact on the company value. International Business Research, 6(5), 1. 


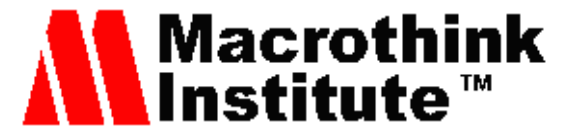

International Journal of Accounting and Financial Reporting ISSN 2162-3082

Prencipe, A. (2004). Proprietary costs and determinants of voluntary segment disclosure: Evidence from Italian listed companies. European Accounting Review, 13(2), 319-340.

Raffournier, B. (1995). The determinants of voluntary financial disclosure by Swiss listed companies. The European Accounting Review, 4(2), 261-280.

Robbins, W. A., \& Austin, K. R. (1986). Disclosure Quality in Government Financial Reports: An Assessment of the Appropriateness of a Compound Measure. Journal of Accounting Research, 24(2), 29-43.

Singhvi, S. S., \& Desai, H. B. (1971). An empirical analysis of the quality of corporate financial disclosure. The Accounting Review, 46, 120-38.

Trabelsi, S., \& Labelle, R. (2006). Evidence that Corporate Websites is a part of the Firm's Overall Disclosure Package. Working paper, Brock University, St. Catherines. Retrieved from http://accounting.uwaterloo.ca/seminars/old_papers/

Uyar, A., \& Kilic, M. (2012). Value relevance of voluntary disclosure: evidence from Turkish firms. Journal of Intellectual Capital, 13(3), 363-376. https://doi.org/10.1108/14691931211248918

Uyar, A., Kilic, M., \& Bayyurt, N. (2013). Association between Firm Characteristics and Corporate Voluntary Disclosure: Evidence from Turkish Listed Companies. Intagible Capital, 9(4), 1080-1112.

Wallace R. S. O., \& Naser, K. (1995). Firm-Specific Determinants of Comprehensiveness of Mandatory Disclosure in the Corporate Annual Reports of Firms on the Stock Exchange of Hong Kong. Journal of Accounting and Public Theory, 14, 311-368.

Wallace, R. S. O. (1987). Disclosure of Accounting Information in Developing Countries: A Case Study of Nigeria. Doctoral Dissertation, University of Exeter, Devon.

Wallace, R. S. O., Naser, K., \& Mora, A. (1994). The Relationship between the Comprehensiveness of Corporate Annual Reports and Firm Specific Characteristics in Spain. Accounting and Business Research, 25, 41-53.

Wang, K., Sewon, O., \& Claiborne. M. C. (2008). Determinants and consequences of voluntary disclosure in an emerging market: Evidence from China. Journal of International Accounting, Auditing and Taxation, 17(1), 14-30.

Weir, C., \& Laing, D. (2001) Governance structure, director independence and corporate performance in the UK. European Accounting Review, 13(2), 86-94.

Xiao, J., Yang, H., \& Chow, C. (2004). The Determinants and Characteristics of Voluntary Internet-Based Disclosures by Listed Chinese Companies. Journal of Accounting and Public Policy, 23(23), 191-225. 


\section{Appendix A. Previous Voluntary Disclosure Score Summary}

\begin{tabular}{|c|c|c|c|}
\hline Previous Researches & Empirical Field & Methodology & $\begin{array}{c}\text { Average of } \\
\text { VD (\%) }\end{array}$ \\
\hline $\begin{array}{l}\text { 1- Singhvi \& Desai } \\
\text { (1971) }\end{array}$ & USA & $\begin{array}{l}\text { Dichotomous - Weighted } \\
\text { Approach }\end{array}$ & 40 \\
\hline 2- Cooke (1989) & Sweden & $\begin{array}{l}\text { Dichotomous - } \\
\text { Unweighted Approach }\end{array}$ & 37 \\
\hline 3- Hossain et al. (1994) & Malaysia & $\begin{array}{l}\text { Dichotomous - } \\
\text { Unweighted Approach }\end{array}$ & 16 \\
\hline 4- Wallace et al. (1994) & Undisclosed & $\begin{array}{l}\text { Dichotomous - } \\
\text { Unweighted Approach }\end{array}$ & Undisclosed \\
\hline 5- Meek et al (1995) & $\begin{array}{c}\text { US, UK, \& } \\
\text { Continental } \\
\text { Europe }\end{array}$ & $\begin{array}{l}\text { Dichotomous - } \\
\text { Unweighted Approach }\end{array}$ & 25 \\
\hline $\begin{array}{l}\text { 6- Deegan and Rankin } \\
\text { (1996) }\end{array}$ & Australia & Quantity Approach & 277 words \\
\hline $\begin{array}{l}\text { 7- Deegan and Gordon } \\
\text { (1996) }\end{array}$ & Australia & Quantity Approach & 186 words \\
\hline 8- Ho and Wong (2001) & Hong Kong & $\begin{array}{l}\text { Non-Dichotomous - } \\
\text { Weighted Approach }\end{array}$ & 29 \\
\hline $\begin{array}{l}\text { 9- Haniffa and Cooke } \\
\text { (2002) }\end{array}$ & Malaysia & $\begin{array}{l}\text { Dichotomous - } \\
\text { Unweighted Approach }\end{array}$ & 31 \\
\hline 10- Eng and Mak (2003) & Undisclosed & $\begin{array}{l}\text { Dichotomous - Weighted } \\
\text { Approach }\end{array}$ & 22 \\
\hline $\begin{array}{l}\text { 11- Naser and Nuseibeh } \\
\text { (2003) }\end{array}$ & $\mathrm{KSA}$ & $\begin{array}{l}\text { Dichotomous - Weighted } \\
\text { \& Unweighted Approaches }\end{array}$ & 34 \\
\hline $\begin{array}{l}\text { 12- Leventis and Weetman } \\
\text { (2004) }\end{array}$ & Greece & Undisclosed & 37 \\
\hline \multirow[t]{2}{*}{ 13- Birt et al. (2004) } & Australia & $\begin{array}{l}\text { Dichotomous - } \\
\text { Unweighted Approach }\end{array}$ & $\begin{array}{cc}41 & (2001) \\
51 & (2002)\end{array}$ \\
\hline & & & $67 \quad(2003)$ \\
\hline 14- Hossain et al (2005) & New Zealand & $\begin{array}{l}\text { Dichotomous - } \\
\text { Unweighted Approach }\end{array}$ & 44 \\
\hline 15- Alsaeed (2005) & Undisclosed & $\begin{array}{l}\text { Dichotomous - } \\
\text { Unweighted Approach }\end{array}$ & 33 \\
\hline
\end{tabular}




\begin{tabular}{|c|c|c|c|}
\hline $\begin{array}{l}\text { 16- Haniffa and Cooke } \\
\text { (2005) }\end{array}$ & Malaysia & Quantity Approach & 275 words \\
\hline 17- Lakhal (2005) & France & $\begin{array}{l}\text { Dichotomous - } \\
\text { Unweighted Approach }\end{array}$ & 56 \\
\hline $\begin{array}{l}\text { 18- Arcay and Vazquez } \\
\text { (2005) }\end{array}$ & Spain & $\begin{array}{l}\text { Dichotomous - Weighted } \\
\text { Approach }\end{array}$ & 48 \\
\hline 19- Akhtaruddin (2005) & Bangladesh & $\begin{array}{l}\text { Dichotomous - } \\
\text { Unweighted Approach }\end{array}$ & 44 \\
\hline $\begin{array}{l}\text { 20- Cheng and Courtenay } \\
\text { (2006) }\end{array}$ & Undisclosed & $\begin{array}{l}\text { Dichotomous for Qualitative } \\
\text { and Quantitative Information }\end{array}$ & 29 \\
\hline $\begin{array}{l}\text { 21- Ghazali and Weetman } \\
\text { (2006) }\end{array}$ & Malaysia & $\begin{array}{l}\text { Dichotomous - } \\
\text { Unweighted Approach }\end{array}$ & 31 \\
\hline 22- Barako et al. (2006) & Kenya & $\begin{array}{l}\text { Dichotomous - Weighted } \\
\text { Approach }\end{array}$ & $\begin{array}{c}\text { Not } \\
\text { Disclosed }\end{array}$ \\
\hline $\begin{array}{l}\text { 23- Hossain and Reaz } \\
\text { (2007) }\end{array}$ & India & $\begin{array}{l}\text { Dichotomous - } \\
\text { Unweighted Approach }\end{array}$ & 35 \\
\hline $\begin{array}{l}\text { 24- Donnely and Mulcahy } \\
\text { (2008) }\end{array}$ & Ireland & $\begin{array}{l}\text { Non-Dichotomous - } \\
\text { Weighted Approach }\end{array}$ & 21 \\
\hline 25- Francis et al (2008) & USA & $\begin{array}{l}\text { Dichotomous - Weighted } \\
\text { Approach }\end{array}$ & 47 \\
\hline 26- Bin Abdullah (2008) & Malaysia & Undisclosed & 25 \\
\hline 27- Al-Shammari (2008) & Kuwait & Undisclosed & 46 \\
\hline 28- Hossain (2008) & India & $\begin{array}{l}\text { Dichotomous - } \\
\text { Unweighted Approach }\end{array}$ & 25 \\
\hline $\begin{array}{l}\text { 29- Hossain and } \\
\text { Hammami (2009) }\end{array}$ & Qatar & $\begin{array}{l}\text { Dichotomous } \\
\text { Unweighted Approach }\end{array}$ & 37 \\
\hline $\begin{array}{l}\text { 30- Elsayed and Hoque } \\
\text { (2010) }\end{array}$ & Egypt & $\begin{array}{l}\text { Dichotomous } \\
\text { Unweighted Approach }\end{array}$ & 55 \\
\hline $\begin{array}{l}\text { 31- Al-Shammari and } \\
\text { Al-Sultan (2010) }\end{array}$ & Kuwait & $\begin{array}{l}\text { Dichotomous } \\
\text { Unweighted Approach }\end{array}$ & 19 \\
\hline 32- Adelopo (2011) & Nigeria & $\begin{array}{l}\text { Dichotomous } \\
\text { Unweighted Approach }\end{array}$ & 44 \\
\hline $\begin{array}{l}\text { 33- Omar and Simon } \\
\text { (2011) }\end{array}$ & Jordan & $\begin{array}{l}\text { Dichotomous - } \\
\text { Unweighted Approach }\end{array}$ & 34 \\
\hline 34- Adawi and & UAE & Non-Dichotomous & 36 \\
\hline
\end{tabular}




\section{Macrothink Institute}

\begin{tabular}{|c|c|c|c|}
\hline Rwegasira (2011) & & Weighted Approach & \\
\hline 35- Al-Janadi et al. (2012) & UAE & $\begin{array}{l}\text { Modified - Unweighted } \\
\text { Approach }\end{array}$ & 42 \\
\hline $\begin{array}{l}\text { 36- Ismail and El-Shaib } \\
\text { (2012) }\end{array}$ & Egypt & $\begin{array}{l}\text { Dichotomous - } \\
\text { Unweighted Approach }\end{array}$ & 51 \\
\hline 37- Al-Janadi et al. (2012) & KSA & $\begin{array}{l}\text { Modified - Unweighted } \\
\text { Approach }\end{array}$ & 32 \\
\hline 38- Uyar et al. (2013) & Turkey & $\begin{array}{l}\text { Dichotomous - } \\
\text { Unweighted Approach }\end{array}$ & 44 \\
\hline 39- Al-Janadi et al. (2013) & KSA & $\begin{array}{l}\text { Modified - Unweighted } \\
\text { Approach }\end{array}$ & 32 \\
\hline $\begin{array}{l}\text { 40- Al Mamum and } \\
\text { Kamardin (2014) }\end{array}$ & Bangladesh & $\begin{array}{l}\text { Dichotomous - } \\
\text { Unweighted Approach }\end{array}$ & 76 \\
\hline 41- Sharma (2014) & Nepal & $\begin{array}{l}\text { Dichotomous - } \\
\text { Unweighted Approach }\end{array}$ & 48 \\
\hline 42- Sawalqa (2014) & Jordan & $\begin{array}{l}\text { Dichotomous - } \\
\text { Unweighted Approach }\end{array}$ & 61 \\
\hline $\begin{array}{l}\text { 43- Charumathi and } \\
\text { Ramesh (2015) }\end{array}$ & India & $\begin{array}{l}\text { Dichotomous - } \\
\text { Unweighted Approach }\end{array}$ & 46 \\
\hline $\begin{array}{l}\text { 44- Kamel and Awadallah } \\
\text { (2017) }\end{array}$ & Egypt & $\begin{array}{l}\text { Dichotomous - } \\
\text { Unweighted Approach }\end{array}$ & 49 \\
\hline 45- El-Diftar et al. (2017) & Egypt & $\begin{array}{l}\text { Dichotomous - } \\
\text { Unweighted Approach }\end{array}$ & 45 \\
\hline 46- Kolsi (2017) & UAE & $\begin{array}{l}\text { Dichotomous - Weighted } \\
\text { Approach }\end{array}$ & 33 \\
\hline
\end{tabular}

\section{Copyright Disclaimer}

Copyright for this article is retained by the author(s), with first publication rights granted to the journal.

This is an open-access article distributed under the terms and conditions of the Creative Commons Attribution license (http://creativecommons.org/licenses/by/4.0/) 